\title{
Studies of Cellular Proliferation in Human Leukemia. I. Estimation of Growth Rates of Leukemic and Normal Hematopoietic Cells in Two Adults with Acute Leukemia Given Single Injec- tions of Tritiated Thymidine*
}

\author{
Bayard Clarkson, $\dagger$ Takeshi Ohkita, Kazuo Ota, $\$$ and Jerrold Fried \\ (From the Divisions of Clinical Chemotherapy and Biophysics, Sloan-Kettering Institute for \\ Cancer Research, and the Department of Medicine, Memorial and James Ewing \\ Hospitals for Cancer and Allied Diseases and Cornell University Medical \\ College, New York, N. Y.)
}

Summary. Two adults with rapidly progressive acute myeloblastic and myelomonoblastic leukemia were given single injections of tritiated thymidine, and measurements were made of the growth rates of their leukemic and normal hematopoietic cells by radioautographic methods. Although almost all leukemic blasts in both marrow and blood were metabolically active as shown by their ability to incorporate tritiated uridine and leucine in vitro, only $5.6 \%$ and $6.1 \%$ of the blasts in the marrow and even fewer in the blood incorporated tritiated thymidine. The mitotic indexes of the marrow blasts were $0.66 \%$ and $0.52 \%$; no circulating blasts were dividing. The mean generation times of the actively proliferating blasts were estimated to be 49 and 83 hours. This cannot be equated with the doubling time of the total leukemic population as there is evidence that many blasts fail to continue dividing and die. The mean durations of the phases of the blasts' mitotic cycles were as follows: DNA synthesis $(S)=22$ and 19 hours, premitosis $\left(G_{2}\right)$ $=3$ hours, mitosis $(M)=0.47$ and 0.62 hour (minimal estimates), and postmitosis $\left(G_{1}\right)=24$ and 61 hours. In both patients the maximal mean transit time of the blasts in the blood was 36 hours, and the minimal numbers of actively dividing blasts present were 1.6 and $2.6 \times 10^{9}$ per $\mathrm{kg}$ of body weight.

Estimates were also made of the rates of proliferation and maturation of the residual normal erythrocytic and granulocytic cells in these two patients. Although total production was markedly diminished because of reduction in the number of normal elements, the relatively few remaining normal cells appeared to be dividing and maturing at rates that are about the same or only slightly slower than those found in normal subjects.

We conclude that the main reason leukemic blasts displace normal hematopoietic precursors in acute leukemia is that the blasts largely fail to differentiate. Many die but many others persist in the marrow and elsewhere as primitive cells and continue to proliferate. As the blasts accumulate, they

* Submitted for publication February 8, 1966; accepted December 9, 1966.

This investigation was supported in part by research grants CA-03215, CA-05826, and CA-08748 from the National Cancer Institute, U. S. Public Health Service.

Presented in part at the Fifty-seventh Annual Meeting of the American Society for Clinical Investigation, Atlantic City, N. J., May 1965. $\dagger$ Address requests for reprints to Dr. Bayard Clarkson, Sloan-Kettering Institute for Cancer Research, New York, N. Y.

¥ Supported by U. S. Public Health Service graduate training grant 5T4 CA5015 from the National Cancer Institute. 


\begin{abstract}
gradually displace the normal hematopoietic cells, most of which continue their normal course of differentiation and leave the marrow as nondividing mature cells. It is not known why the over-all production of normal cells is not adequately increased to compensate for the anemia, granulocytopenia, and thrombocytopenia that develop, but apparently the leukemic cells somehow interfere with the proliferation or differentiation or both of normal stem cells.
\end{abstract}

\section{Introduction}

Although there have been recent advances in knowledge about normal hematopoiesis (1-8), information is still limited about cellular proliferation in acute leukemia (8-14). The present report is a study of two adults with acute leukemia in whom in vivo measurements were made of the mean generation times of their leukemic cells and of the phases of their mitotic cycles. Estimates were made of the total numbers of dividing leukemic cells and of their mean transit times in the blood. Insofar as possible, the rates of proliferation and maturation of residual normal hematopoietic cells and their times of emergence into and disappearance from the blood were also measured.

\section{Methods}

\section{Injection of thymidine- ${ }^{s} \mathrm{H}$ and preparation of radioauto- graphs}

Twenty mc of tritiated thymidine (thymidine- ${ }^{3} \mathrm{H}, 6.6 \mathrm{c}$ per mmole) ${ }^{1}$ was injected intravenously during 5 minutes; for reasons to be presented later it appears unlikely that this dose significantly disturbed the mitotic cycle. At intervals thereafter, about $0.05 \mathrm{ml}$ of marrow was aspirated from either the sternum or anterior or posterior iliac crest, and smears were made directly. Five- to $10-$ $\mathrm{ml}$ samples of blood were placed in dried heparinized tubes. After centrifugation in silicone-treated tubes, most of the plasma was removed and smears were made of the buffy coat. Fifteen to 20 smears were made of each specimen on gelatinized slides and immediately dried with a hairdryer. The slides were then fixed in absolute methyl alcohol for 15 minutes, air dried, and stored until the experiment was completed. All radioautographs were processed together as previously described (15), with a single shipment of Kodak AR 10 radioautographic stripping film. All film shipments were tested for background activity before use on nonradioactive buffy coat smears. Only film with an average of less than 1 grain per nucleated cell in areas that had the highest background was used. The radioautographs for the in vivo studies were exposed for 2 or 4 weeks, developed, and stained with Giemsa at $\mathrm{pH} 5.7$.

${ }^{1}$ Schwarz Bioresearch, Orangeburg, N. Y.

\section{In vitro studies}

Two to $10 \mathrm{ml}$ of marrow or blood was diluted with 2 vol of Gey's solution containing approximately $10 \mathrm{U}$ of heparin per ml. Samples were placed in test tubes to which were added separately thymidine ${ }^{3} \mathrm{H}$ and uridine- ${ }^{3} \mathrm{H}$ (SA $200 \mathrm{mc}$ per mmole each) or leucine- ${ }^{3} \mathrm{H}$ (SA $400 \mathrm{mc}$ per mmole) to give final concentrations of 0.05 to $0.2 \mu \mathrm{c}$ per $\mathrm{ml}$ for thymidine ${ }^{3} \mathrm{H}$ and 0.2 to $1.0 \mu \mathrm{c}$ per $\mathrm{ml}$ for uridine $-{ }^{3} \mathrm{H}$ and leucine $-{ }^{3} \mathrm{H}$. The tubes were incubated at $37^{\circ} \mathrm{C}$ in a shaking water bath for 15 minutes to 29 hours. After centrifugation, the buffy coat was taken off, and smears were made and processed for radioautographs as previously described; they were exposed for 2 weeks for the thymidine $-{ }^{3} \mathrm{H}$ and 8 weeks for the uridine $-{ }^{3} \mathrm{H}$ and leucine- ${ }^{3} \mathrm{H}$ experiments. In general, the amount of isotope incorporated per cell varied directly with the isotopic concentration and inversely with the cellular concentration.

\section{Mitotic index and counting of labeled cells}

The mitotic index was determined by counting the number of blasts in mitosis among 5,000 or more blasts on direct smears and was expressed as a percentage. All recognizable stages of mitosis were counted (except early prophase). One hundred or more blast mitoses were counted for determining the fraction of labeled mitoses, and 1,000 to 5,000 interphase blasts for the fraction of labeled blasts. To avoid false positives, we chose a counting threshold of 5 grains ${ }^{2}$; all cells with fewer grains were considered unlabeled for purposes of obtaining labeling indexes, median grain counts, and so on. For grain count distributions, 100 or more labeled interphase cells and 50 or more labeled mitoses were tabulated and their grain counts plotted in increments of 10 except for the group with the lowest count ( 5 to 9,10 to 19 , and so on up to 90 to 99 ). Cells with 100 or more grains were grouped together. The assumptions concerned with the use of thymidine $-{ }^{3} \mathrm{H}$ for studying cellular proliferation have previously been considered in detail $(9,15,17-23)$.

2 The grain count distribution due to background activity obeys the Poisson probability law (16). The mean background grain count of slides counted was about 35 grains per hundred cells, with a maximum of about 60 grains per hundred. At this maximal background level, $45 \%$ of the cells have at least 1 grain due to background, $12 \%$ have at least 2 grains, $2 \% 3$ or more, $0.3 \% 4$ or more, and only $0.04 \%$ will have greater than 4 . 
After intravenous injection in man, thymidine- ${ }^{8} \mathrm{H}$ is rapidly catabolized and is available to cells for incorporation into DNA for only about 20 minutes (24).

\section{Phases of mitotic cycle and generation time}

The nomenclature for the mitotic cycle phases is as follows (25): DNA synthesis, $\mathrm{S}$; premitosis, $\mathrm{G}_{2}$; mitosis, $\mathrm{M}$; and postmitosis, $\mathrm{G}_{1}$. The mean duration of $\mathrm{S}$ was measured as the time between the midpoints of the rising and falling curves of per cent labeled mitoses $(15,22)$. The a) minimal, $b)$ median, and $c$ ) maximal durations of $\mathrm{G}_{2}$ are defined as the times between administration of thymidine $-{ }^{3} \mathrm{H}$ and, respectively, $a$ ) the appearance of the first labeled mitotic figure, $b$ ) when $50 \%$ and c) $100 \%$ of mitoses are labeled $(15,22,26)$. These estimates of course include a portion of the mitotic phase, but this was ignored. Providing that all blasts are proliferating and cells leaving the marrow do so randomly, it can be shown by an adaptation of the method of Cleaver (27) that the duration of $\mathrm{M}$ is, $\mathrm{T}_{\mathrm{M}}=$ [mitotic index $(\mathrm{MI}) \times$ mean generation time $\left.\left(\mathrm{T}_{\mathrm{G}}\right)\right] / 0.693$. If some blasts are not dividing, the true MI of the proliferating fraction is higher than the apparent $\mathrm{MI}$, and the true $T_{M}$ will be longer. The divisor 0.693 enters because of the assumption of random passage to the blood. Although blasts probably pass into the blood preferentially in $\mathrm{G}_{1}$ (as shown by the facts that the initial labeling index is lower in the blood than in the marrow, and that no mitotic blasts are found in the blood), this would probably result in only a small increase in the divisor. At worst, the divisor could be as large as unity; this would be the case if blasts could pass to the blood only immediately after mitosis. Since it is more likely that they can do so during most of $G_{1}$, the actual divisor is probably close to the one used.

The mean generation time $\left(T_{G}\right)$ of the blasts was measured as the time taken for the median grain count of the more highly labeled cells to halve. The first median grain count used $\left(\mathrm{I}_{0}\right)$ was that after the majority of labeled cells had completed their first division (about 24 hours), since the time between administration of thymidine $-{ }^{3} \mathrm{H}$ and the first division includes only a portion of the mitotic cycle. The subsequent halving of the grain count $\left(I_{0 / 2}\right)$ then reflects the generation time.

The number of labeled blasts counted for each sample was 100 to 200 ; the $40 \%$ or $50 \%$ of cells with the highest grain counts were used. This fraction is large enough that little error is introduced even if the population is highly variable. On the other hand, by utilizing only the more highly labeled cells we were able to follow their median grain count for a longer period, resulting in a more accurate estimate of the generation time. A complicating factor encountered in the use of this technique is that the daughters of lightly labeled cells may fall below the counting threshold upon division. Their exclusion has the effect of artificially raising the median grain count of "labeled" cells, resulting in an overestimation of $T_{G}$. To correct for this, we assumed that the decrease in labeling index was due entirely to cells falling below the threshold after division, and the fraction of labeled cells used for the median grain count estimate was increased proportionally to the decrease in labeling index. Since mitoses were not observed in the blood, we assumed that division occurs only in the marrow and that the blood data represent a smoothed out, delayed version of the situation in the marrow with a time lag of about a day. The marrow data were considered more accurate than the blood. The actual procedure used to estimate $T_{G}$ (15) was to obtain a least-squares fit (28) of a straight line to a semilogarithmic plot of the median grain count versus time. The numerical calculations were performed on a Control Data Corporation 160A digital computer.

The duration of $G_{1}$ was determined by subtracting the total of the measurable phases $\left(S, G_{2}\right.$, and $\left.M\right)$ from $T_{G}$.

\section{Blood transit time and total number of dividing blasts}

The mean transit time of cells in the blood is defined as the average time spent in the blood (9). This is equal to the $t_{\frac{1}{2}}$ for disappearance of highly labeled cells from the blood (calculated by the method of least squares) divided by 0.693 . The grain count threshold is chosen sufficiently high that relatively few cells entering from the marrow during the period of measurement will have grain counts in this range, and "recirculating" cells that might return to the blood after dividing elsewhere will no longer have counts above this threshold. A threshold of 60 grains was selected; if a higher one was used, there were too few cells to obtain valid results.

The method used to estimate the total number of dividing blasts in the marrow is based on the assumptions that $a$ ) the system is in a steady state; $b$ ) cell death in the marrow is negligible, and all cells are proliferating; c) cells passing from the marrow into the blood do so randomly with respect to phase of mitotic cycle; and $d$ ) there is little recirculation of proliferating blasts from blood to marrow. If the system is growing or if marrow cell death is significant, the estimate will be too low; if $c$ or $d$ is invalid, it will be too high. As mentioned earlier in connection with derivation of the expression for $T_{M}$, it is unlikely that the fact that assumption $c$ is not strictly correct will cause significant error in the result. There is evidence (see Discussion) that assumption $d$ is probably valid. Therefore it is probable that error due to factors $a$ and $b$ is of greater significance than $c$ and $d$, and the expression presented here for the number of dividing blasts will be considered a minimal estimate. The expression is derived by equating the rate at which new blasts are produced in the marrow to the rate at which they leave the blood: $\left(0.693 / \mathrm{T}_{\mathbf{G}}\right) \times \mathrm{N}_{\mathbf{M}}=$ $(1 / \tau) \mathrm{N}_{B}$, or $\mathrm{N}_{M}=\mathrm{T}_{\mathrm{G}} \mathrm{N}_{\mathbf{B}} / 0.693 \tau$, where $\mathrm{T}_{\mathrm{G}}=$ mean generation time, $\mathrm{N}_{M}=$ number of dividing blasts in the marrow, $\tau=$ mean transit time of blasts in the blood, and $\mathrm{N}_{\mathrm{B}}=$ number of blasts in the blood.

The blood volume was assumed to be $66.5 \mathrm{ml}$ per $\mathrm{kg}$ of body weight (29).

\section{Normal erythrocytic and granulocytic cells}

Normal hematopoietic cells were classified mainly according to conventional morphologic criteria (30). Gen- 

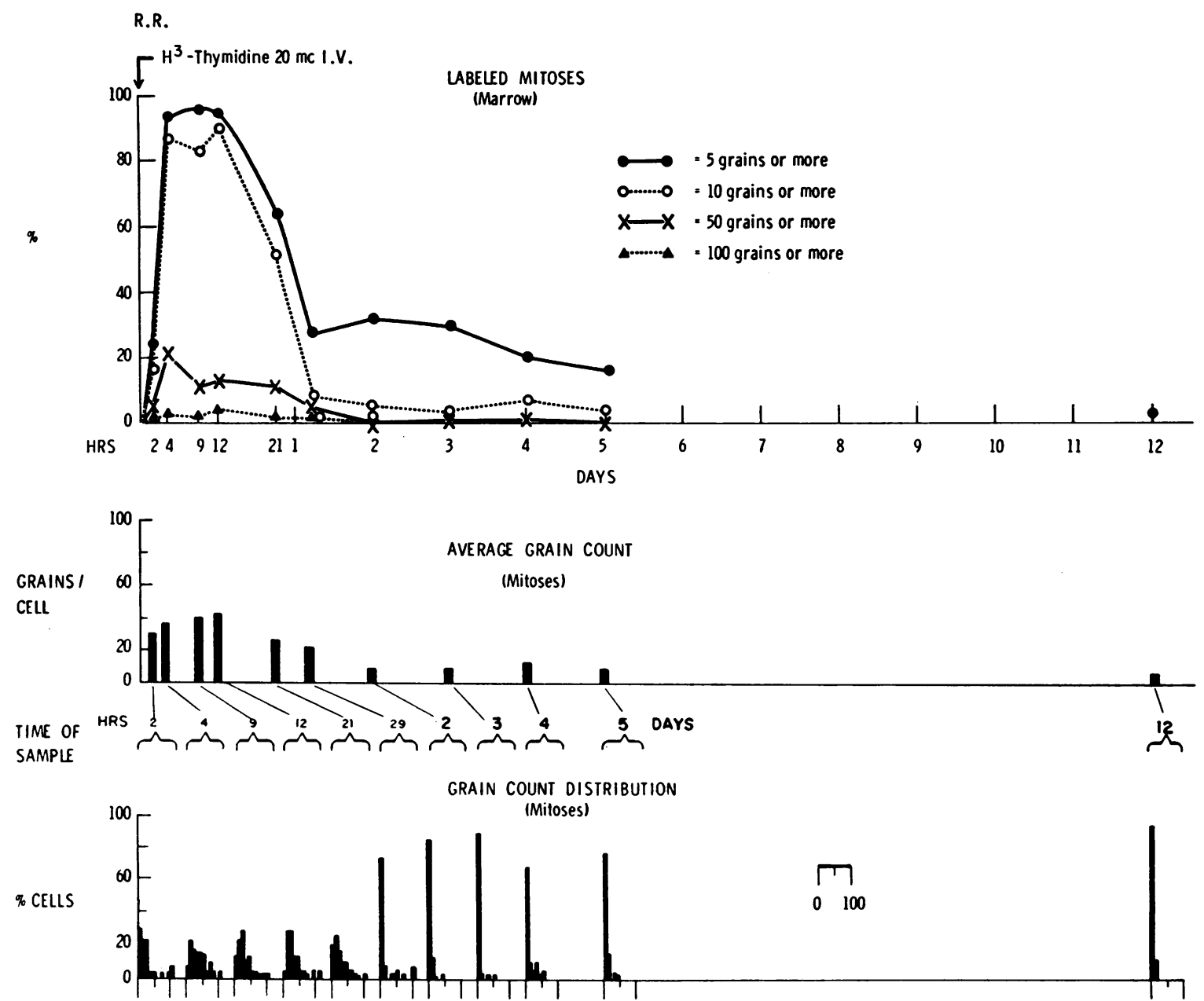

GRAINS / CELLS

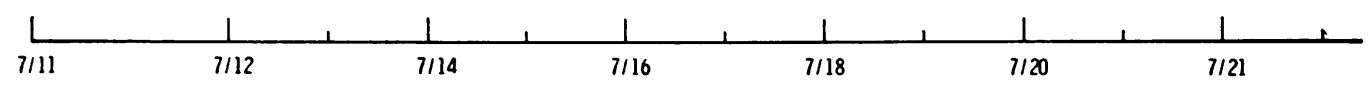

Fig. 1. Time of appearance of LAbeled blasts in mitosis in R.R. The duration of the plateau of maximal labeled mitoses and the true shape of the descending curve are uncertain because no samples were obtained between 12 and 21 hours. Radioautographs exposed 2 weeks.

erally, the principles and methods formulated by investigators at Brookhaven National Laboratory (2-4, $6,17,31,32$ ) were used to measure the rates of proliferation and maturation of these cells. For comparative purposes we have also used the same criteria and nomenclature for erythropoietic cells $(6,17,32)$. Cells were classified by morphologic criteria except in ambiguous cases, where size was also considered.

The proportional distribution of red cell precursors was determined by counting 1,000 or more of these cells. Five hundred or more polychromatic normoblasts were counted for the mitotic index. For determining the percentage of labeled cells, 25 or more basophilic normoblasts, 50 or more metamyelocytes, and 100 or more polychromatic or orthochromatic normoblasts, bands, and polymorphonuclear cells were counted.

\section{Case reports}

Subject 1, R.R. R.R., a 68-year-old woman, was diagnosed elsewhere as having acute leukemia in May 1963, 1 month after she had excessive bleeding following extraction of several teeth. She was given $2,500 \mathrm{ml}$ of whole blood, and prednisone (100 $\mathrm{mg}$ per day) was started on June 14, 1963. There was little improvement and she was admitted to James Ewing Hospital on July 10, 1963. Numerous ecchymoses and petechiae were present. There was no detectable enlargement of the lymph nodes, liver, or spleen. The hematocrit was $19 \%$, 

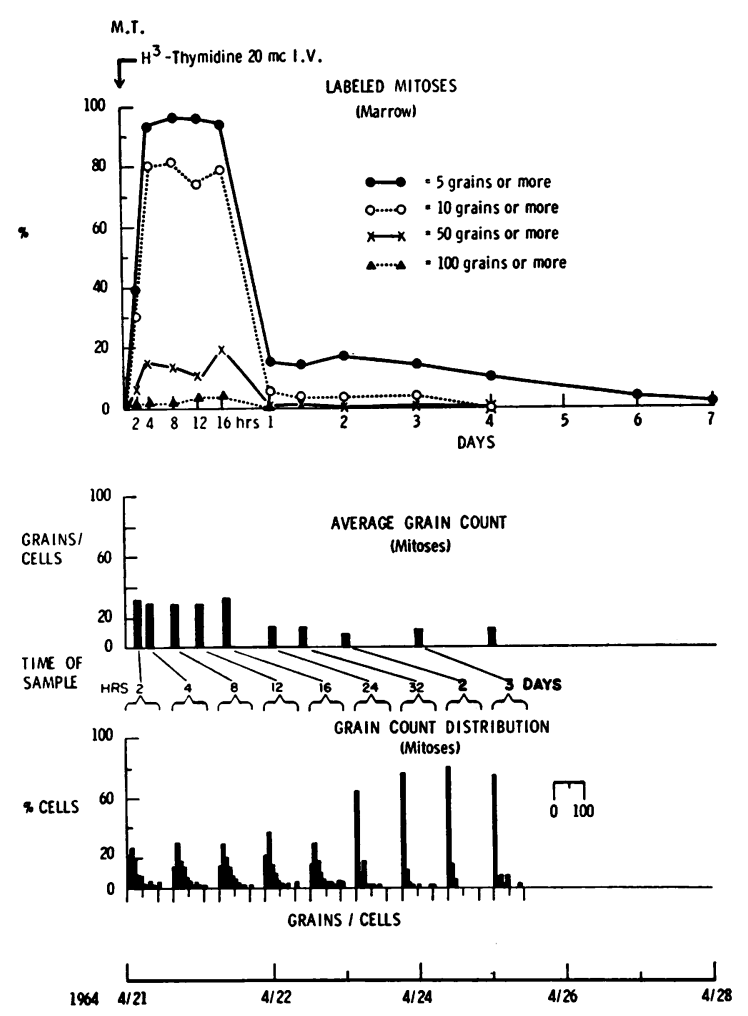

Fig. 2. Time of appearance of Labeled blastS in MitosIS IN M.T. Radioautographs exposed 2 weeks.

hemoglobin level $5.8 \mathrm{~g}$ per $100 \mathrm{ml}$, leukosytes 23,000 per $\mathrm{mm}^{3}$, and platelets 3,000 per $\mathrm{mm}^{3}$; the peripheral blood differential showed polymorphonuclear neutrophiles $17 \%$, bands $6 \%$, monocytes $8 \%$, lymphocytes $16 \%$, atypical lymphocytes $3 \%$, metamyelocytes $2 \%$, blasts $48 \%$, and nucleated red cells $2 \%$. A sternal marrow aspirate was very hypercellular, and the differential was as follows: blasts $76.2 \%$, promyelocytes $6.0 \%$, myelocytes $2.8 \%$, metamyelocytes $2.2 \%$, bands $4.4 \%$, polymorphonuclear neutrophiles $3.4 \%$, eosinophiles $0.2 \%$, monocytes $1.0 \%$, lymphocytes $3.2 \%$, nucleated red cell precursors $0.4 \%$, and plasma cells $0.2 \%$. Some of the blasts had Auer bodies. No megakaryocytes were seen and there were no megaloblastic changes. A diagnosis was made of acute myeloblastic leukemia. Almost all cells classified as "promyelocytes" were abnormal; however, as it was often not possible to distinguish them from blasts in the radioautographs, they were grouped together as "blasts."

Prednisone was discontinued, and $20 \mathrm{mc}$ of thymidine- ${ }^{3} \mathrm{H}$ $(0.26 \mu \mathrm{c}$ per $\mathrm{g}$ of body weight) was injected on July 11 , the day after admission. Because she had been running a low grade fever, thought to be due to bronchopneumonia, tetracycline was started on July 15 ; her temperature returned to normal and remained so thereafter. Other than $1,000 \mathrm{ml}$ of whole blood, no further treatment was given until July 16, when 6-mercaptopurine and thiadiazole were started as part of a clinical trial to see whether the latter would enhance the therapeutic effect of the purine analogue. The leukocyte count gradually fell and there was a slight improvement in the peripheral blood differential, but the platelet count remained low and the marrow remained hypercellular without any improvement in the differential. Her clinical condition worsened rapidly. Prednisone was begun again on July 23 , but there was no improvement and she died 3 days later as a result of an intracranial hemorrhage. Postmortem examination showed a generalized bleeding diathesis. The marrow was densely packed with blasts, and there was moderate infiltration of leukemic cells in the liver, spleen, lymph nodes, renal cortices, and submucosa of the stomach and intestine. The liver and spleen weighed $1,500 \mathrm{mg}$ and $200 \mathrm{~g}$, respectively.

Subject 2, M.T. M.T., a 61-year-old woman, was admitted to another hospital on March 4, 1964, because of weakness and dyspnea, and a diagnosis of acute leukemia was made. She was given prednisone $(20 \mathrm{mg}$ per day) and $1,500 \mathrm{ml}$ of whole blood and discharged on March 21, 1964. She was admitted to James Ewing Hospital on April 18, 1964, because of recurrent weakness. She had a few petechiae and ecchymoses of the skin, and the spleen tip was just palpable. The lymph nodes and liver were not enlarged. The hemoglobin level was $6.3 \mathrm{~g}$ per $100 \mathrm{ml}$, hematocrit $20 \%$, leukocytes 15,000 per $\mathrm{mm}^{3}$, and platelets 11,000 per $\mathrm{mm}^{3}$. The peripheral blood differential showed polymorphonuclear neutrophiles $1 \%$, lymphocytes $10 \%$, and blasts $89 \%$. A sternal marrow aspirate was very cellular and had the following differential: lymphocytes $10 \%$, polychromatophilic and orthochromatic normoblasts $4 \%$, monocytes $4.5 \%$, and blasts $81.5 \%$. The blasts were interpreted as monoblasts by some hematologists; others thought they had mixed features of myeloblasts and monoblasts. Occasional Auer bodies were seen. About $4 \%$ of the polychromatic normoblasts and metamyelocytes and more mature erythrocytic and granulo:ytic forms showed minor megaloblastic or macrocytic changes; these were absent in the earlier precursors.

On April 21, 1964, $20 \mathrm{mc}$ of thymidine- ${ }^{3} \mathrm{H}$ ( $0.34 \mu \mathrm{c}$ per $\mathrm{g}$ of body weight) was injected. Her clinical condition remained fairly stable, and no treatment was given during the next week except $2,000 \mathrm{ml}$ of whole blood. The leukocyte count fell spontaneously to around 8,000 per $\mathrm{mm}^{3}$.

On April 28, 1964, a continuous intravenous infusion of 5-fluoro-2'-deoxyuridine (FUdR) was started and continued for 5 days. She developed moderate gastrointestinal toxicity and the leukocyte count fell to 4,500 per $\mathrm{mm}^{3}$, but the marrow remained hypercellular with over $90 \%$ blasts. Her subsequent course was complicated by a pararectal abscess and bilateral pyelonephritis, both of which responded poorly to antibiotics. Beginning May 18,1964 , she received three intravenous injections of vincristine over the next 11 days. The peripheral leukocyte count fell from 10,800 per $\mathrm{mm}^{3}$ to 1,100 per $\mathrm{mm}^{3}$, the platelets from 30,000 per $\mathrm{mm}^{3}$ to 5,000 per $\mathrm{mm}^{3}$, and the marrow became hypocellular. She then developed pneumonia, septicemia, and jaundice and died in shock on June 3, 1964. 
R.R.

$\%$
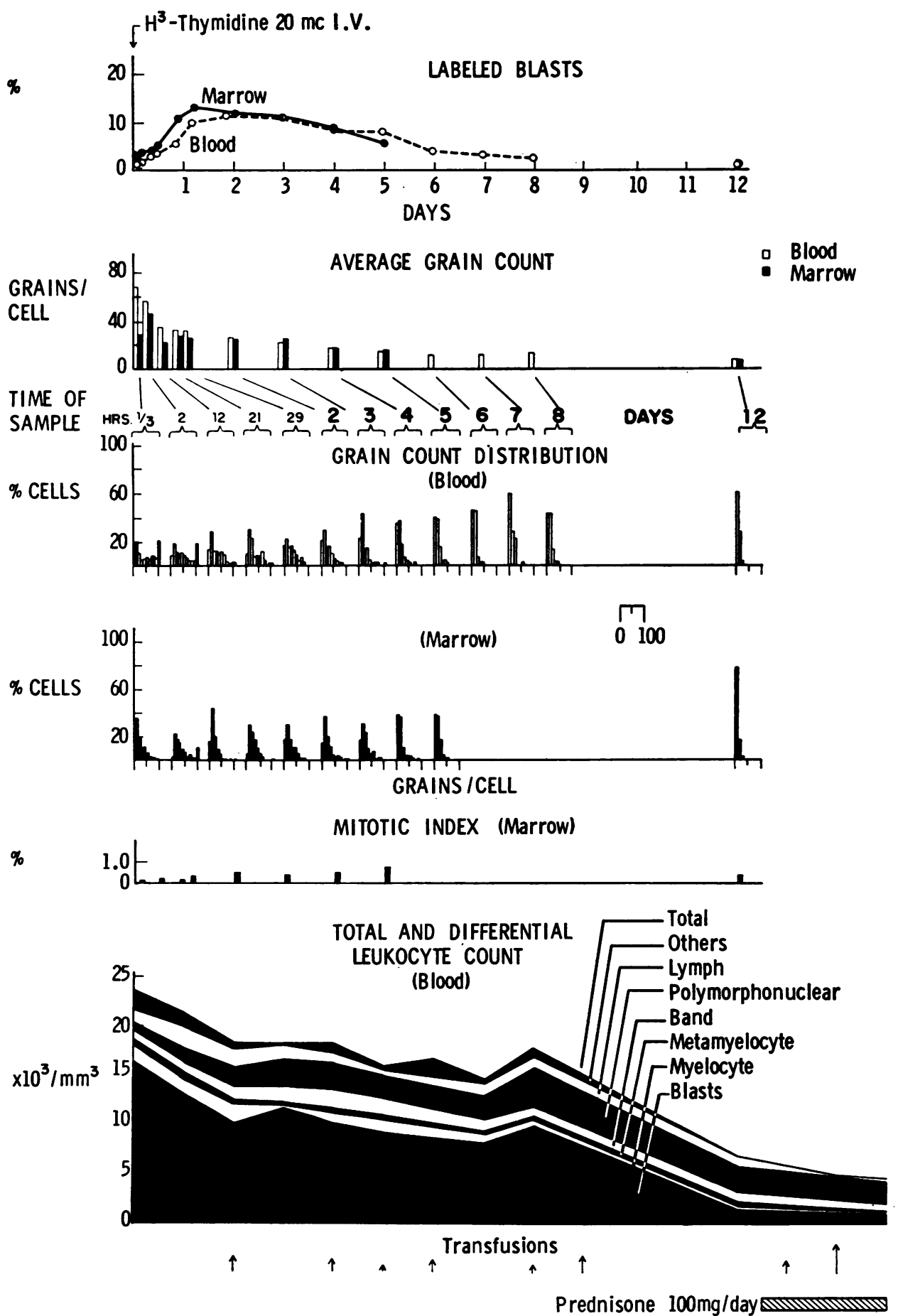

6-MP $175 \mathrm{mg} /$ day

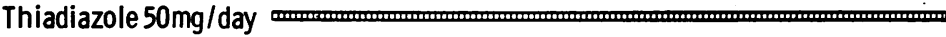

1963

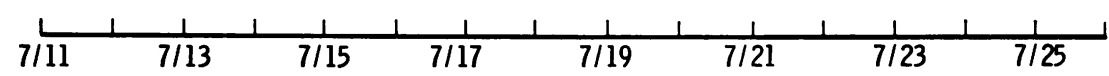

Fig. 3. Time of APPEARANCE OF LABELED INTERPH ASE BLASTS IN R.R. Radioautographs exposed 2 weeks. $6-\mathrm{MP}=6$-mercaptopurine. 

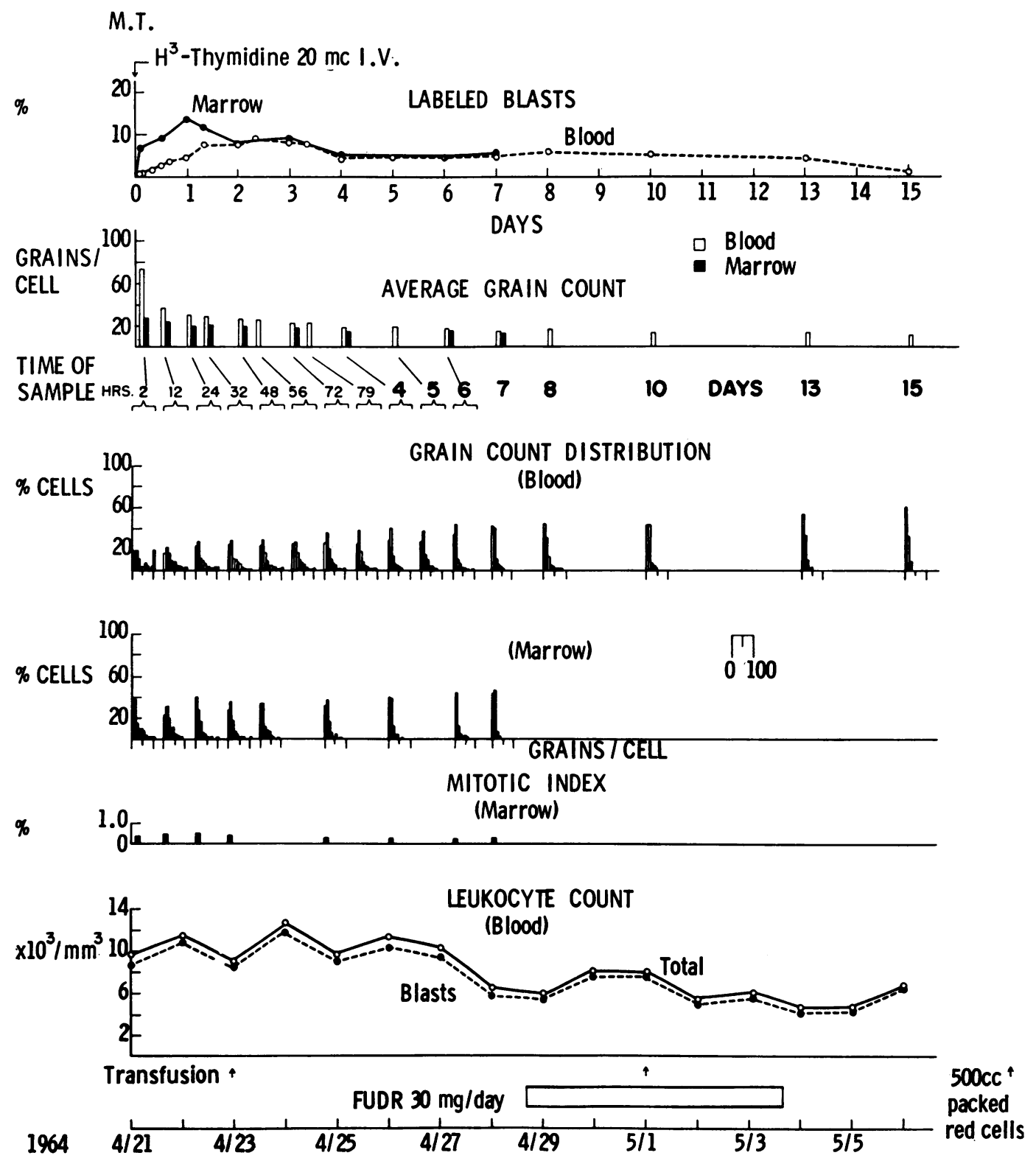

Fig. 4. Time of appearance of labeled interph ase blasts in M.T. Radioautographs exposed 2 weeks. $F U d R=5$-fluoro-2'-deoxyuridine.

\section{Results}

Mitotic indexes and labeled blast mitoses

Before injection of thymidine- ${ }^{3} \mathrm{H}$, the mitotic index (MI) of the marrow blasts was $0.44 \%$ in patient R.R. and $0.28 \%$ in patient M.T. During the studies it varied between $0.1 \%$ and $0.66 \%$ (average $0.28 \%$ ) in the 11 marrow samples from R.R. (Figure 1) and between $0.23 \%$ and $0.52 \%$ (average 0.36 ) in the 12 samples from M.T.
(Figure 2). The lower values were presumably largely due to greater dilution with blood (no mitotic figures were found in the blood), and the highest values probably most nearly represent the true MI. Although direct evidence is lacking, it seems probable that the MI remained more or less constant during the study since the variations appeared to correlate with the cellularity of the sample and occurred randomly rather than in a diurnal or consistent manner. 
The times of appearance of labeled blasts in mitosis in the marrow in R.R. and M.T. are shown in Figures 1 and 2. A small percentage of mitoses was almost certainly truly unlabeled at the tops of both curves, since when the radioautographic exposure time was doubled and 100 blast mitoses in each sample were recounted, their average grain counts approximately doubled but 2 to $4 \%$ still had no grains at all.

J.t is apparent that the relative numbers of highly and lightly labeled mitoses did not change appreciably until about the end of the first day, after which most of the persistent labeled mitoses had a low labeling intensity. It is highly probable that the latter were truly labeled, since the average background grain count as determined by counting 1,000 "unlabeled" interphase cells (i.e., those with less than 5 grains) was less than 1 grain per cell, and only $2 \%$ or less of both "unlabeled" interphase cells and "unlabeled" mitoses had 4 grains. Furthermore, by exposing the radioautographs 4 weeks and raising the grain count threshold to 7 or 8 grains (not shown), the percentages of labeled mitoses were almost identical to those found at the 5-grain threshold in Figures 1 and 2.

\section{Durations of phases of mitotic cycle}

$G_{2}$ phase. The median duration of $\mathrm{G}_{2}$ was about 3 hours in both patients. The minimum was between 20 minutes and 2 hours in R.R. and is unknown in M.T. because no specimen was obtained earlier than 2 hours. The maximal duration of $\mathrm{G}_{2}$ is uncertain since not all mitoses were labeled. The few unlabeled mitoses at the tops of the curves appeared no different from the labeled ones, and it is probable that either $a$ ) their $\mathrm{G}_{2}$ phases were longer than 12 to 16 hours, $b$ ) the combined duration of $G_{2}$ plus $S$ was shorter than this, or $c$ ) they were so situated that they were not exposed to a sufficient concentration of thymidine $-{ }^{3} \mathrm{H}$ to become labeled.

$S$ phase. The mean duration of $\mathrm{S}$ was 21.6 hours in R.R. and 18.7 hours in M.T. The grain counts of the mitoses did not change significantly during the first day, when most of the labeled cells underwent their first division; hence the average rate of incorporation of thymidine ${ }^{3} \mathrm{H}$ must have been approximately constant during the $\mathrm{S}$ phase. The explanation for the persistence of (mostly lightly) labeled mitotic figures after the first day is uncertain; they did not differ morphologically from the unlabeled mitoses. By comparing the grain count distribution data in Figures 1 and 3 , and in 2 and 4 , it is apparent that the mitotic blasts and interphase blasts no longer shared a similar grain count distribution after the first day (i.e., more of the mitoses had a low labeling intensity). Although a few of the persistent labeled mitoses (i.e., those with 10 or more grains) may have had a very long $G_{2}$ phase, this cannot account for the 15 to $30 \%$ that remained labeled. No clear second rising wave of labeled mitoses was observed; this may have been due either to an insufficient number of samples or else to rapid loss of synchrony of the labeled population after their first division. One possible explanation for the persistent labeled mitoses is reutilization of thymidine- ${ }^{3} \mathrm{H}$; this has been demonstrated in vivo in a number of experimental systems by others (33-39). However, the per cent of interphase cells with 5 or more grains in the marrow fell progressively after 24 to 29 hours (Figures 3 and 4 , top graphs), and there was no increase in the number containing 1 to 4 grains (not shown). Another possibility is that some of the persistent labeled mitoses were cells with a low DNA synthesis rate associated with a very long $S$ phase; these blasts would incorporate less thymidine- ${ }^{3} \mathrm{H}$ than the majority, which divided earlier. Finally it is possible that some blasts had very short generation times and were undergoing second divisions. Since most mitoses after 1 day were lightly labeled, it may be that the more highly labeled cells were inhibited from undergoing second and later divisions as a result of thymidine- ${ }^{3} \mathrm{H}$ toxicity.

$M$ phase. If we assume that the highest mitotic indexes found in the marrow are most nearly correct, for R.R., minimal duration of $T_{M}=[0.66 /$ $100(\mathrm{MI}) \times 49$ hours $\left.\left(\mathrm{T}_{\mathrm{G}}\right)\right] / 0.693=0.47$ hours; for M.T., minimal duration of $\mathrm{T}_{\mathbf{M}}=[0.52 / 100$ $(\mathrm{MI}) \times 83$ hours $\left.\left(\mathrm{T}_{\mathrm{G}}\right)\right] / 0.693=0.62$ hours.

$G_{1}$ phase. For R.R., the average $G_{1}=24$ hours; and for M.T., 61 hours.

\section{Labeled interphase blasts}

In R.R.'s marrow $3.0 \%$ of the blasts were labeled at 20 minutes and $3.4 \%$ at 2 hours (Figure 3 , top graph). In the blood, $0.6 \%$ and $0.7 \%$ were 


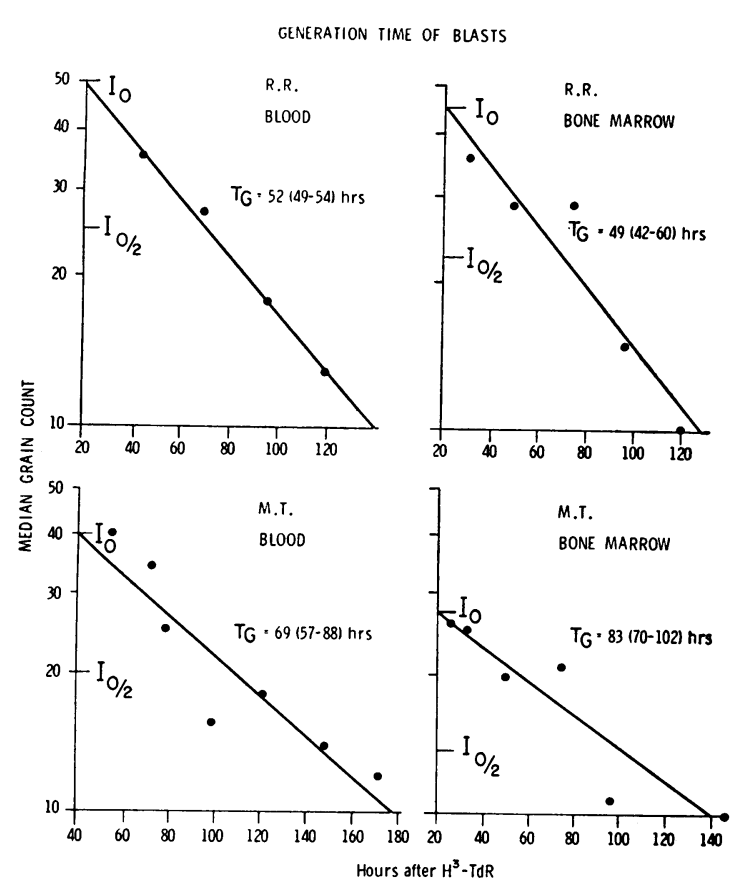

Fig. 5. Generation time ( $\mathrm{T}_{G}$ ) OF blasts in Blood AND MARROW OF R.R. AND M.T. AS MEASURED BY THE HALVING TIME OF THE MEDIAN GRAIN COUNT $\left(\mathrm{I}_{0 / 2}\right)$ OF, RESPECTIVELY, THE $50 \%$ AND $40 \%$ (OR MORE) MOST HIGHLY LABELED BLASTS. See text for description of method. Radioautographs exposed 2 weeks. $\mathrm{TdR}=$ thymidine.

labeled at 20 minutes and 2 hours, respectively. The percentage of labeled blasts reached a maximum of $13 \%$ in the marrow at 29 hours and $11.5 \%$ in the blood at 45 hours and thereafter slowly declined. It will be noted that the per cent of labeled blasts in R.R.'s marrow more than doubled in the first 29 hours. Possible explanations are thymidine ${ }^{3} \mathrm{H}$ reutilization or repeated divisions of labeled blasts, but we consider the major factor more likely to be that the earlier marrow samples were more diluted with peripheral blood and hence their (apparent) labeling index was too low. The latter proposal is supported by the observation that the mitotic indexes were lower in the earlier samples (Figure 3, mitotic index). Even if diluted to the same degree, the labeling indexes of the later marrow samples would be less affected, since the labeling index in the blood increased to approximate that in the marrow by the second day (Figure 3, top graph).

In M.T.'s marrow, $6.1 \%$ of the blasts in the marrow were labeled in the initial 2-hour sample, and $0.2 \%$ of those in the blood were labeled at 1 hour (Figure 4, top graph). The labeled blasts reached a peak of $13.5 \%$ in the marrow at 24 hours and $9.1 \%$ in the blood at 56 hours and then gradually fell.

\section{Generation times of blasts}

The calculated values for $T_{G}( \pm 1 S D$ on a logarithmic scale) were as follows: R.R. $=49$ (42 to 60 ) hours in the marrow and 52 (49 to 54) hours in the blood, and M.T. $=83$ (70 to 102 ) hours in the marrow and 69 (57 to 88 ) hours in the blood (Figure 5).

\section{Mean transit time of blasts in blood}

The calculations of blood transit times of blasts were based on the disappearance times of circulating blasts having 60 or more grains (Figure 6). The starting points for the computations were chosen to be the times at which the absolute numbers of these blasts were maximal. The observed half-times for disappearance $\left(T_{D}\right)$ were $25(21$ to 30 ) hours for R.R., and 25 (21 to 32 ) hours for M.T. These times are upper limits since it is known that some cells with more than 60 grains were still present in the marrow (Figures 3 and 4 , grain count distribution data), and presumably some of these were still entering the blood during the period of observation. The mean transit time of the blasts in the blood was 36 hours in both patients.

In the initial blood samples about half the la-

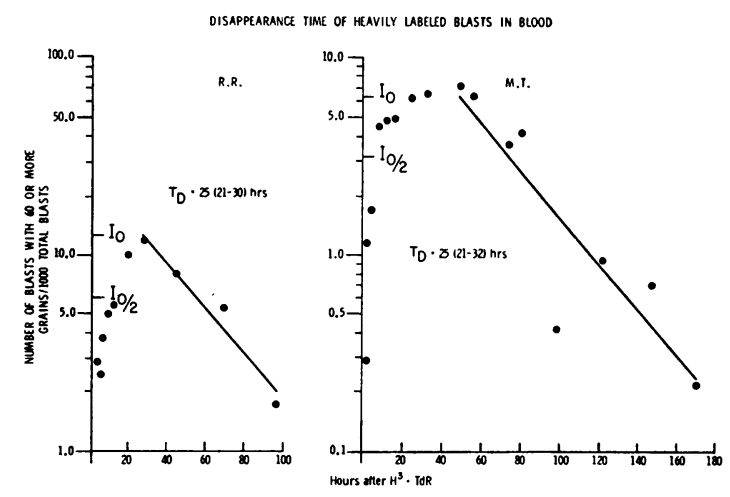

Fig. 6. Rate of disappearance $\left(T_{D}\right)$ of Labeled BLASTS WITH 60 OR MORE GRAINS FROM BLOOD OF R.R. AND M.T. See text for description of method. Radioautographs exposed 2 weeks. 
beled cells had 60 or more grains ( $48 \%$ at 20 minutes for R.R. and $54 \%$ at 1 hour for M.T.), presumably due to a higher concentration of thymidine $-{ }^{3} \mathrm{H}$ in the venous blood than in the marrow immediately after injection (Figures 3 and 4, compare grain count distribution in marrow and blood). The percentage of labeled blasts in the blood with 60 or more grains thereafter fell progressively, due both to loss of highly labeled cells from the blood and to influx of labeled cells from the marrow, most of which were less highly labeled. Nevertheless, because some of the marrow blasts were highly labeled, the absolute numbers of circulating blasts with 60 or more grains (per 1,000 total blasts) rose to maximal values at 29 hours in R.R. and 49 hours in M.T.; they then fell until none were found after 96 hours in R.R. or after 195 hours in M.T.

\section{Total number of dividing blasts}

The average number of blasts in R.R.'s blood during the period of study was 12,000 per $\mathrm{mm}^{3}$, and with an estimated blood volume of $5,000 \mathrm{ml}$ the total number of circulating blasts $\left(\mathrm{N}_{\mathrm{B}}\right)$ was $60 \times 10^{9}$. Since their mean transit time $(\tau)$ was 36 hours, each hour $60 \times 10^{9} / 36=1.7 \times 10^{9}$ blasts entered the blood, and the same number of mitoses must have occurred to maintain this number. The total number of dividing blasts $\left(\mathrm{N}_{\mathbf{M}}\right)$,

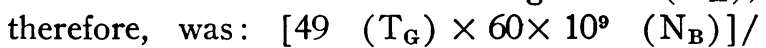
$[0.693 \times 36(\tau)]=12 \times 10^{10}$; or $\left(12 \times 10^{10}\right) / 76$ $\mathrm{kg}=1.6 \times 10^{9}$ per $\mathrm{kg}$ of body weight.

In M.T., the average number of circulating blasts during the study was 11,700 per $\mathrm{mm}^{3}$, and with a blood volume of $3,900 \mathrm{ml}$ the total number of circulating blasts was $45.6 \times 10^{9} . \quad \mathrm{N}_{\mathbf{M}}=[83$ $\left.\left(T_{G}\right) \times 45.6 \times 10^{9} \quad\left(\mathrm{~N}_{B}\right)\right] /\left[\begin{array}{lll}0.693 \times 36 & (\tau)\end{array}\right]=$ $15 \times 10^{10}$; or $\left(15 \times 10^{10}\right) / 58.5 \mathrm{~kg}=2.6 \times 10^{9}$ per $\mathrm{kg}$ of body weight.

Incorporation of uridine ${ }^{3} \mathrm{H}$, leucine ${ }^{3} \mathrm{H}$, and thymidine ${ }^{3} \mathrm{H}$ in vitro

All of both R.R.'s and M.T.'s blasts from both marrow and blood utilized uridine ${ }^{3} \mathrm{H}$ and leucine $-{ }^{3} \mathrm{H}$ in vitro, and the amount incorporated was almost maximal by 4 hours. The percentage of R.R.'s blasts that were labeled in vitro immediately with thymidine $-{ }^{3} \mathrm{H}$ and their average grain

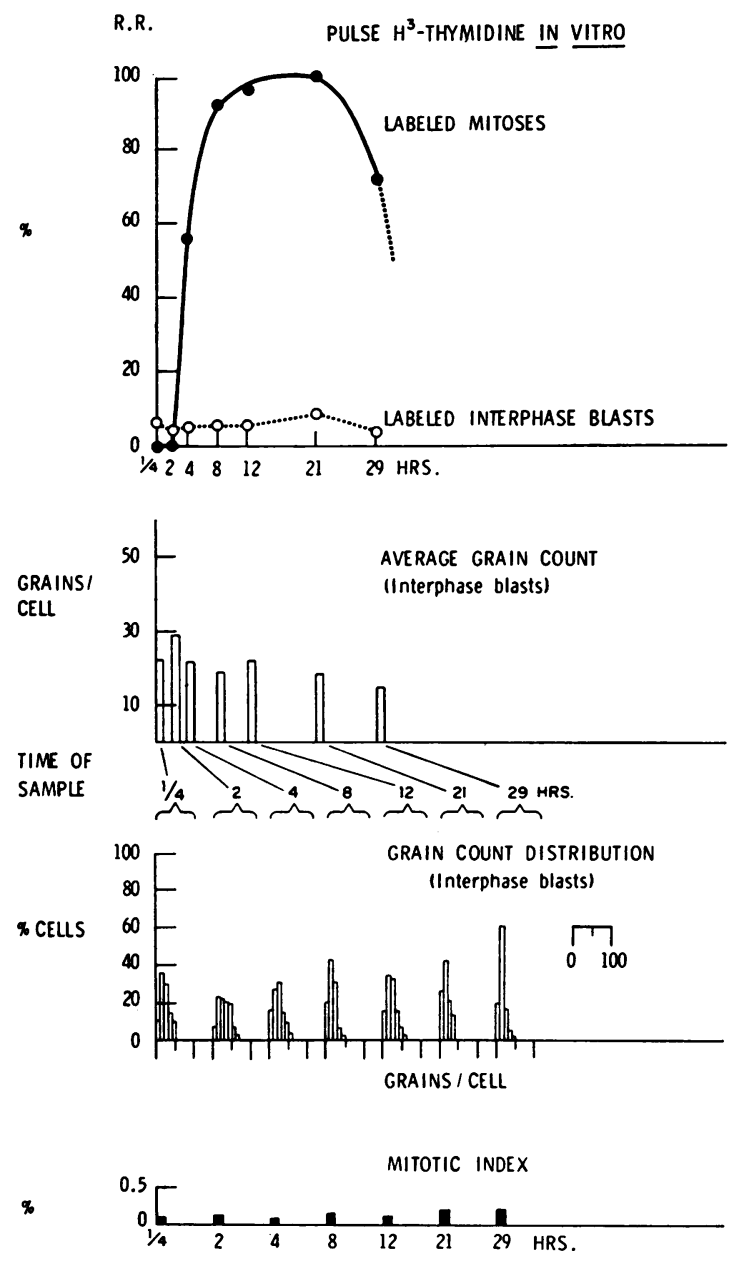

Fig. 7. Time of appearance of LABELEd BLASTS IN MITOSIS AFTER PULSE LABELING OF R.R.'S MARROW IN VITRO FOR 20 MINUTES WITH THYMIDINE- ${ }^{3} \mathrm{H}$. [SA $200 \mathrm{mc}$ per mmole, concentration $0.05 \mu \mathrm{c}$ per $\mathrm{ml}\left(=2.5 \times 10^{-4}\right.$ mmole per L).] Labeled thymidine was then removed and replaced with excess nonradioactive thymidine $(2.5 \times$ $10^{-4}$ mole per $\left.\mathrm{L}\right)$. Concentration of nucleated cells in incubation mixture $=55,000$ per $\mathrm{mm}^{3}$. Radioautographs exposed 2 weeks.

counts were as follows: blood $=1.3 \%, 86$ grains; marrow $=5.6 \%, 45$ grains (peripheral leukocytes $=20,000$ per $\mathrm{mm}^{3}$; undiluted marrow $=149,850$ nucleated cells per $\mathrm{mm}^{3}$ ). The maximal average grain count occurred at 4 hours, and the per cent of labeled blasts did not change appreciably over 29 hours. Since M.T.'s marrow and blood were not incubated with thymidine- ${ }^{3} \mathrm{H}$ until after the latter had been given in vivo, the results may not be valid and are therefore not presented.

A pulse labeling experiment was also done in 


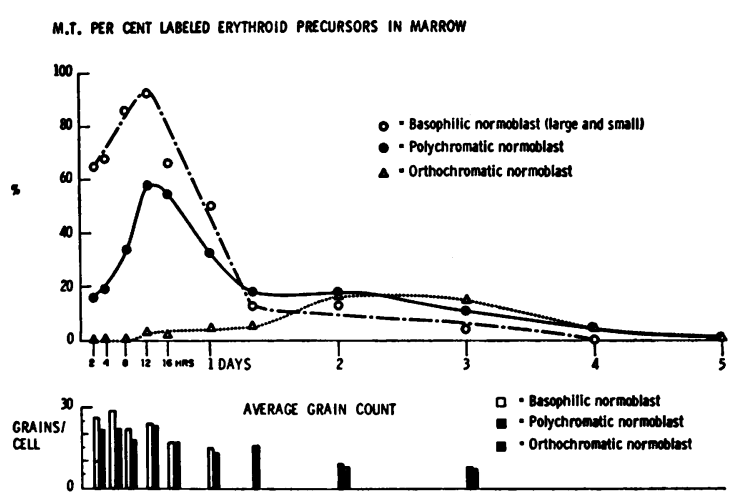

Fig. 8. Time of appearance of Labeled erythroid PRECURSORS IN MARROW AFTER INTRAVENOUS INJECTION OF THYMIDINE- ${ }^{8} \mathrm{H}$ IN M.T. Radioautographs exposed 2 weeks.

which R.R.'s marrow blasts were exposed to thymidine- ${ }^{3} \mathrm{H}\left(2.5 \times 10^{-4}\right.$ mmole per $\left.\mathrm{L}\right)$ for only 20 minutes (Figure 7). The cells were then centrifuged, the supernatant was removed, and the cells were resuspended in autologous serum and Gey's solution containing 1,000-fold excess of nonradioactive thymidine ( 0.25 mmole per $\mathrm{L})$. The blasts' mitotic index was only $0.1 \%$; this low value undoubtedly was a result of dilution with peripheral blood, as a total of $10 \mathrm{ml}$ of "marrow" was aspirated for this experiment. The minimal duration of $\mathrm{G}_{2}=$ greater than 2 hours, median $\mathrm{G}_{2}=4$ hours, and mean $\mathrm{S}=27$ hours (measured from projection of descending curve to $50 \%$ level). Compared to the time of appearance of labeled mitoses in vivo, there was significant prolongation of DNA synthesis and delayed entry into mitosis. Excess thymidine (about 2 to 5 mmoles per L) has been shown to block DNA synthesis and suppress mitotic activity in several mammalian cell types grown in vitro (40-44). Other possible factors causing delay in passage of cells through the mitotic cycle in vitro are trauma associated with aspiration of marrow and the fact that the cells remained at room temperature for about 45 minutes while being prepared for incubation.

\section{Labeling of normal hematopoietic cells}

To evaluate the nature of the disturbance in normal hematopoiesis in acute leukemia, we followed the time course of thymidine- ${ }^{3} \mathrm{H}$ labeling of our patients' residual normal hematopoietic cells.

Erythropoiesis. The ratios of proerythroblasts: large basophilic normoblasts:small basophilic normoblasts : polychromatic normoblasts : orthochromatic normoblasts were as follows: for R.R., $1: 4.7: 2.0: 30.6: 17.3$; and for M.T., $1: 6.3: 3.3$ : $43.5: 71.0$. The mitotic index of the polychromatic normoblasts was $1.6 \%$ for R.R. and $4.7 \%$ for M.T. There were too few earlier precursors to determine their mitotic index with any reliability.

For M.T., the percentages of cells initially labeled ( 2 hours after thymidine ${ }^{3} \mathrm{H}$ ) and their average grain counts were these: proerythroblasts, 80\%, 40 grains (only 10 cells found); large and small basophilic normoblasts, $65 \%$, 26 grains; and polychromatic normoblasts, $16 \%$, 22 grains (Figure 8 ). From halving of the average grain count by the method of least squares (not shown), the generation time of the basophilic normoblasts was calculated to be $30 \pm 7$ hours and of the polychromatic normoblasts $48 \pm 8$ hours. These are maximal estimates, since the average grain counts of all labeled cells were used because there were too few to select just the most highly labeled. They must also be regarded as only rough approximations, since no correction was made for influx or efflux of labeled cells into and out of these maturation compartments. Labeled orthochromatic normoblasts first appeared at 12 hours and reached a maximum at 48 hours.

In R.R., the percentage of cells initially labeled (at 2 hours) and their average grain counts were as follows: proerythroblasts, $60 \%, 150$ grains (only 10 cells found); large and small basophilic normoblasts, 48\%, 42 grains; and polychromatic normoblasts, 10\%, 32 grains. The basophilic normoblasts reached a peak of $84 \%$ at 21 hours and the polychromatic normoblasts $62 \%$ at 21 hours. The rate of disappearance of labeled erythroid precursors in R.R. was slower than in M.T., and their (maximal) generation times, as calculated from halving of their average grain counts, were longer: basophilic normoblasts $=56 \pm 6$ hours, and polychromatic normoblasts $55 \pm 7$ hours. No orthochromatic normoblasts were labeled at 12 hours or earlier, and the maximal percentage labeled was $25 \%$ at 21 hours.

Granulopoiesis. M.T. had too few granulocytes to obtain reliable counts. Two hours after injec- 

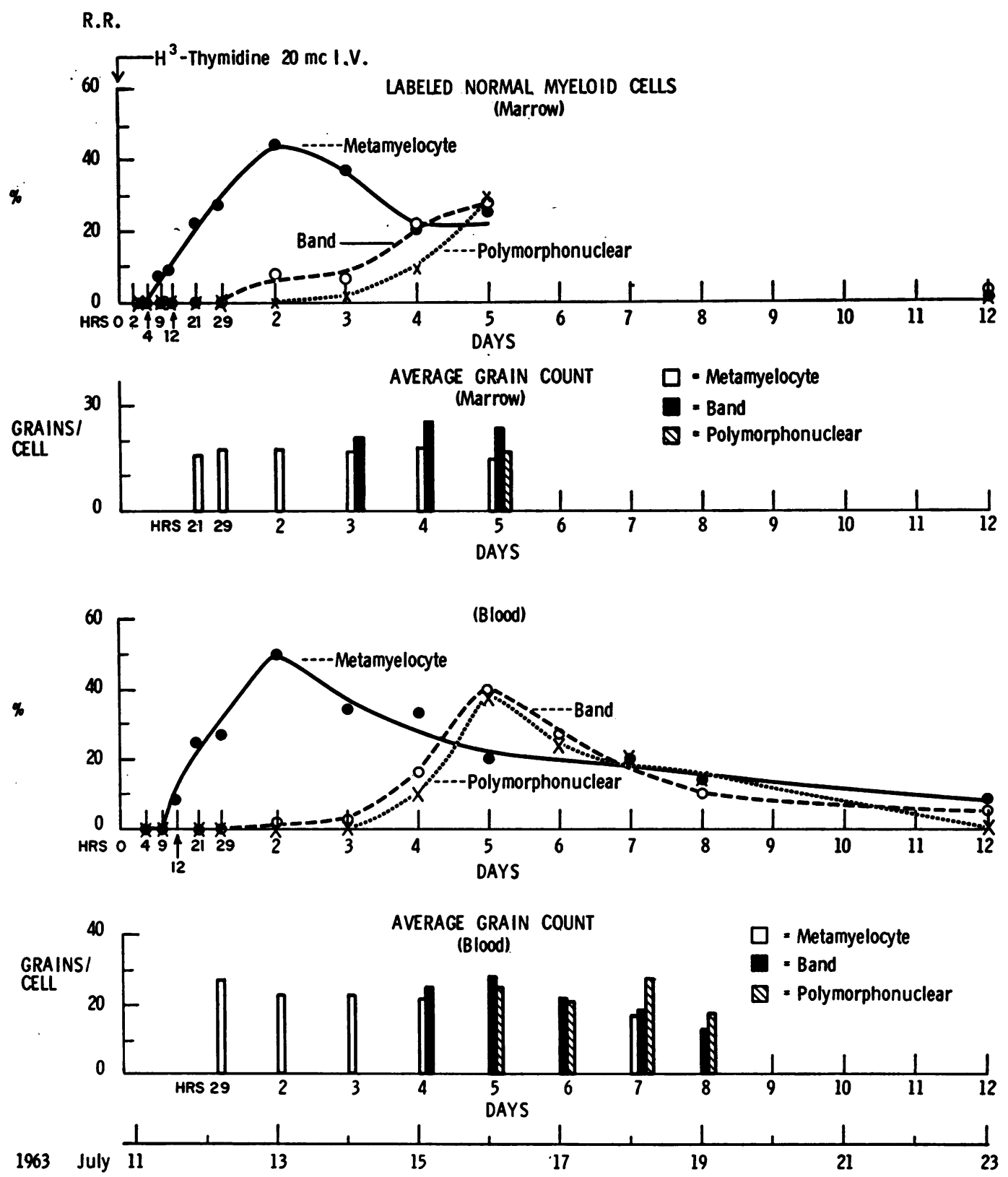

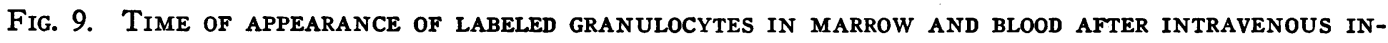
JECTION OF THYMIDINE- ${ }^{-3} \mathrm{H}$ IN R.R. Radioautographs exposed 2 weeks.

tion in R.R., $7 \%$ of the myelocytes in the marrow and $8.5 \%$ of those in the blood were labeled, and the average grain count of each was 42 . The percentage of labeled myelocytes increased rapidly to $67 \%$ in the marrow at 12 hours and to $80 \%$ in the blood at 29 hours. They then declined until only 3 and $5 \%$ remained labeled at 12 days in the marrow and blood, respectively. Although most of the myelocytes appeared morphologically normal, it will be recalled that there were $6 \%$ promyelocytes in the marrow (which were all assumed to be leukemic), and it is possible that some of the myelocytes may also have been leukemic. They are, therefore, not charted with the more mature granulocytes, which were all assumed to be normal (Figure 9). 
TABLE I

Estimated parameters of proliferation of leukemic blasts and normal myeloblasts*

\begin{tabular}{|c|c|c|c|}
\hline & \multicolumn{2}{|c|}{ Leukemic blasts } & \multirow{2}{*}{$\begin{array}{l}\text { Myeloblasts in subjects with } \\
\text { normal hematopoiesis }\end{array}$} \\
\hline & R.R. & M.T. & \\
\hline $\begin{array}{l}\text { Per cent in DNA synthesis } \\
\quad \text { (initial LI) }\end{array}$ & $\begin{array}{l}5.6 \\
1.3\end{array}$ & $\begin{array}{l}6.1 \text { (marrow) } \\
0.2 \text { (blood) }\end{array}$ & $32-85(10,12,13,31,45) \dagger$ \\
\hline Mitotic index, $\%$ & 0.66 & 0.52 (marrow) & $2.5(46)$ \\
\hline $\begin{array}{l}\text { Mean duration } \mathrm{S} \\
\text { phase, hours }\end{array}$ & 22 & 19 & $13-14(7,8) ; 6(47)$ \\
\hline $\begin{array}{l}\text { Median duration } \mathrm{G}_{2} \\
\text { phase, hours }\end{array}$ & 3 & 3 & ? $2(6,8)$ \\
\hline $\begin{array}{l}\text { Mean duration M phase, } \\
\text { hours }\end{array}$ & 0.47 & 0.62 & $0.6(1)$ \\
\hline $\begin{array}{l}\text { Mean duration } \mathrm{G}_{1} \text { phase, } \\
\text { hours }\end{array}$ & 24 & 61 & ? 13-32 \\
\hline $\begin{array}{l}\text { Mean generation time, } \\
\text { hours }\end{array}$ & 49 & 83 & $30-48(1,18,31)$ \\
\hline $\begin{array}{l}\text { Mean blood transit time, } \\
\text { hours }\end{array}$ & 36 & 36 & \\
\hline $\begin{array}{l}\text { Total number dividing } \\
\text { blasts, per } k g\end{array}$ & $1.6 \times 10^{9}$ & $2.6 \times 10^{9}$ & \\
\hline
\end{tabular}

${ }^{*} \mathrm{LI}=$ labeling index. $\quad$ Nomenclature for mitotic cycle phases $: \mathrm{S}$ phase $=\mathrm{DNA}$ synthesis $; \mathrm{G}_{2}$ phase $=$ premitosis $;$ $\mathrm{M}$ phase $=$ mitosis $; \mathrm{G}_{1}$ phase $=$ postmitosis.

$\dagger$ References for normal values given in parentheses.

\section{Discussion}

In Table I are listed the parameters of proliferation that were measured in the leukemic blasts of R.R. and M.T. and the corresponding values for normal myeloblasts as given in the literature. Some of the latter information $(6-8,17,18,31)$ was obtained from the study of only one or two subjects who were in a normal steady hematopoietic state, and the range of normal values is not known.

\section{Percentage of blasts synthesizing DNA}

The percentage of leukemic blasts in the marrow that was engaged in DNA synthesis at any one time is considerably lower than that of normal myeloblasts (Table I). This is in keeping with previous studies of patients with acute leukemia in whom the percentages of marrow blasts initially labeled with thymidine- ${ }^{3} \mathrm{H}$ were as follows: $6.1 \%(0.2$ to $9.1 \%)(10), 7.9 \%$ (2.2 to $26.5 \%)$ (48), $9.9 \%$ (3.0 to $24 \%$ ) (49), and $9 \%$ (4.1 to $17.3 \%$ ) (13). The initial labeling indexes of our patients' circulating blasts were even lower than in the marrow, again in keeping with most other studies in which both leukemic marrow and blood were studied $(9,13,49-51)$. Roll and Killmann
(52) have reported that the labeling index of leukemic blast cells in the blood of four patients with untreated acute leukemia remained essentially constant at different times of the day.

The maximal initial (thymidine ${ }^{3} \mathrm{H}$ ) labeling indexes (those found in vitro) were taken as the most nearly correct values for R.R.'s leukemic blasts. It is not clear why their labeling index was higher in vitro than in vivo, as in most other patients we have studied, the values agree very closely. Possible explanations include the following: a) blasts synthesizing DNA at a marginal rate may have reached the labeling threshold only in vitro where the thymidine $-{ }^{3} \mathrm{H}$ concentration is higher; or (in the case of marrow), $b$ ) sampling differences; or $c$ ) some blasts may have been under hypoxic or other adverse conditions in vivo and only begun DNA synthesis in vitro.

\section{Mitotic index}

In confirmation of previous studies $(13,53)$, the leukemic marrow blasts in our patients had lower mitotic indexes than those reported for normal myeloblasts $(46,54)$, and the leukemic cells did not divide in the blood. The data of Killmann, Cronkite, Fliedner, and Bond (46) were 
used for normal myeloblasts for comparative purposes in Table I, but none of the previous studies are exactly comparable because different techriques were used. In 12 other patients with acute leukemia whom we have studied the average mitotic index of the marrow blasts was $0.71 \%(0.2$ to $1.16 \%$ ) and of the circulating blasts $0.01 \%$ $(0.0$ to $0.08 \%)(51,55)$. These are minimal values for the marrow blasts, since there is always some dilution with blood. Almost all blasts in both blood and marrow were metabolically active in these as well as in other patients with acute leukemia whom we have studied (51), as indicated by incorporation of uridine- ${ }^{3} \mathrm{H}$ and leucine- ${ }^{3} \mathrm{H}$.

\section{Duration of phases of mitotic cycle}

The only comparable measurements of the duration of DNA synthesis in normal granulocyte precursors are in two patients in whom it was estimated to be 13 to 14 hours $(7,8)$. Ota $(56)$ has studied the appearance times of labeled blast mitoses in vivo in three additional patients with acute leukemia, and in all three the duration of $\mathrm{S}$ was roughly 20 hours. The duration of the $\mathrm{S}$ phase of R.R.'s blasts in vitro was somewhat longer ( 27 hours), probably due in part to the inhibitory effect of excess nonradioactive thymidine (40-44), and in part to nonphysiological conditions in vitro.

The grain count data in both our patients indicated that the over-all average rate of thymidine- ${ }^{3} \mathrm{H}$ incorporation was roughly constant during the $S$ phase in most of the labeled blasts. However, it is possible that in some, DNA synthesis may have occurred at a significantly slower rate, and the method used gives no information about variability in individual cells. Different results have been reported in different cell types growing in vivo or in vitro under different experimental conditions. In some studies (57-59) the rate of thymidine- ${ }^{3} \mathrm{H}$ incorporation during DNA synthesis has been almost constant, whereas in others the cells have shown nonuniformity in rate of labeling (60-63). Significant differences have been noted in the rate of thymidine- ${ }^{3} \mathrm{H}$ incorporation among different pairs or groups of human leukemic chromosomes and also between different segments of individual chromosomes (64).

The median duration of $\mathrm{G}_{2}$ was about 3 hours in our patients' blasts with a minimum of less than 2 hours. The duration of $G_{2}$ was not stated for normal granulocyte precursors, but from published labeled mitoses curves $(6,8)$ the median appears to be around 2 hours.

The minimal duration of the mitotic phase of our patients' leukemic blasts (about 0.5 to 0.6 hour) was about the same as that found for normal myeloblasts (1). Boll and Kühn (65) by direct observation timed the duration of 93 myelocyte and 1 myeloblast mitoses in vitro in normal human marrow cultures and found the mean mitotic time to be 88 minutes; in leukemic myeloblasts, the mean duration of mitosis was significantly longer (142 minutes).

\section{Generation time}

The mean generation time of normal myeloblasts has been estimated to be about 30 to 48 hours, whereas in our patients' blasts it was 49 and 83 hours $(1,18,31)$. Killmann and his associates (9) found the mean generation time of the blasts in one patient with acute myeloblastic leukemia to be about 80 hours and in another with acute blastic transformation of chronic granulocytic leukemia to be about 50 hours. We have studied 12 other patients with acute leukemia and estimated the mean generation time of the blasts to be between 76 and 215 hours $(51,55,56)$. These values were determined by the same methods employed in the present study except that no correction was made for decrease in the per cent of labeled blasts during the period of measurement (see Methods); in cases where this was significant, the true generation times are shorter than previously stated (by roughly one-third).

On the basis of changes occurring in the per cent of labeled blasts in the marrow and their grain counts during the first day or later after one or more injections of thymidine ${ }^{3} \mathrm{H}$ in several children with acute leukemia, Mauer has concluded that only about 20 to $30 \%$ of the blasts in the marrow were actively proliferating and that their generation time was around 20 hours $(11,48,66)$. This is about the time we found for the mean duration of $\mathrm{S}$, and although it is possible that some blasts have a shorter $\mathrm{S}$ phase and may begin to synthesize DNA again almost immediately after dividing, this estimate of the generation time ap- 
pears to us to be too short for the majority of proliferating blasts. Furthermore, since a small rapidly proliferating population of blasts would rapidly outnumber a larger nonproliferating population, such a situation could not exist for long. Many of our results as well as their interpretation are different from those reported by Mauer, but we are presently unable to fully explain the discrepancies because of the different techniques employed. Part of the explanation may lie in the fact that we deliberately avoided using grain count changes that occurred during the first day after thymidine- ${ }^{3} \mathrm{H}$ administration in measuring $\mathrm{T}_{\mathbf{G}}$. We waited until conditions had more or less equilibrated between the marrow and blood compartments since grain count changes are rather unpredictable during the first day due to unequal labeling intensity in the different compartments. In addition, the time between thymidine ${ }^{3} \mathrm{H}$ administration and the first division does not encompass a full mitotic cycle, but disregards the $G_{1}$ phase, which according to our results accounts for the greater part of $T_{G}$. It should also be noted that almost all of our studies have been in adults; although we have not found any consistent differences in $T_{G}$ of blasts in different types of acute leukemia, no definite conclusions can be made until comparable studies in adults and children have been performed.

Using the rate of increase in the percentage of leukemic cells in the marrow of children with acute leukemia whose disease was undergoing relapse, Frei and Freireich (67) found that the observed slopes on a semilogarithmic plot were consistent with a 4 or 5-day doubling time of the leukemic cells. By a similar method of analysis, Ellison and Murphy (68) estimated that the doubling time of blasts in lymphoblastic leukemia (children and adults) was $5 \frac{1}{2}$ to 6 days, whereas in acute myeloblastic leukemia in adults it was about 10 days. In these studies it was assumed that all blasts were proliferating; if only a portion were dividing, their generation time would of course be shorter.

The current investigation provides no direct evidence about what fraction of leukemic blasts is actively proliferating. However, we have previously reported the results of continuous infusions of thymidine- ${ }^{3} \mathrm{H}$ for 8 to 10 days in four patients with acute leukemia (51). At the end of the infusions, 82 to $93 \%$ of blasts in both marrow and blood were labeled, and their mean generation times were similar to those found in patients to whom we gave single injections of thymidine- ${ }^{3} \mathrm{H}$. This strongly suggests that the majority of blasts undergo DNA replication (and presumably then divide) at least once during the 8- to 10 -day period. On the other hand, if all blasts were proliferating, the labeling index would be related to the fraction of $\mathrm{T}_{\mathrm{G}}$ occupied by $\mathrm{S}(69)$, and the following relationship should be valid (27):

Initial labeling index (LI)

$$
\begin{aligned}
\cong \exp \left[0.693\left(\frac{\mathrm{T}_{\mathrm{G}_{2}}+\mathrm{T}_{\mathrm{M}}}{\mathrm{T}_{\mathrm{G}}}\right)\right] \\
\times\left\{\exp \left[0.693\left(\frac{\mathrm{T}_{\mathrm{S}}}{\mathrm{T}_{\mathrm{G}}}\right)\right]-1\right\},
\end{aligned}
$$

where $T_{G_{2}}, T_{M}$, and $T_{s}=$ the durations of the respective phases. For R.R., calculated LI= $38.2 \%$, whereas observed LI $=5.6 \%$. For M.T., calculated $\mathrm{LI}=17.8 \%$, whereas observed $\mathrm{LI}=$ $6.1 \%$.

Obviously the observed initial labeling indexes of the marrow blasts in the present two patients are too low, even taking into account that these values are minimal ones because of dilution with peripheral blood. We believe that the most plausible explanation to reconcile these apparently contradictory observations is that many of the daughter cells of dividing blasts fail to divide again and instead die. Nondividing blasts cannot persist in the marrow for long; if they had, fewer blasts would have been labeled at the end of the continuous infusions. It is presently uncertain whether many blasts die in situ in the marrow or whether most of them pass into the circulation to die, but the latter seems more probable.

An important consideration is whether the leukemic blasts that die are those that have undergone some degree of maturation or become senile in a manner analogous to the life cycle of normal cells. Small leukemic blasts have been reported to have a much lower initial thymidine- ${ }^{3} \mathrm{H}$ labeling index than large (and presumably younger) blasts $(14,66)$; this has been interpreted to mean that leukemic blasts may grow older and lose their proliferative capacity without maturing. How- 
ever, in many cases of acute leukemia the blasts do undergo some degree of maturation, and it is in fact their ability to partially differentiate that enables one to diagnose the morphologic type of leukemia. The circulating cells are frequently more mature than those in the marrow. A number of such cases with morphologically heterogeneous blasts have been studied after thymidine $-{ }^{3} \mathrm{H}$ administration, and it has been demonstrated that the more mature cells may stop proliferating $(8,13,51,55,56)$. Most of the blasts in R.R. and M.T. were fairly uniform morphologically, and although some showed partial differentiation toward promyelocytic or monocytoid forms, there were not enough such cells and their morphologic features were generally too imprecise to allow correlation between different stages of maturity and different thymidine- ${ }^{3} \mathrm{H}$ labeling patterns.

These points should be emphasized: a) $\mathrm{T}_{\mathrm{G}}$ as used in this study is a measure of the mean generation time of that cohort of blasts which was synthesizing DNA at the time thymidine- ${ }^{3} \mathrm{H}$ was given. It is the average time between two consecutive mitoses of the actively dividing blasts and should not be confused with the doubling time of the entire leukemic population $(67,68)$, which will be longer since some blasts are dormant or die. b) $\mathrm{T}_{\mathrm{G}}$ is merely a mean value, and the present studies afford no information about the variability of generation times beyond suggesting that some blasts may have very short generation times ( 1 to 2 days). Our continuous infusion studies indicate considerable variability with some blasts' generation times being longer than 10 days $(51,55)$. The extremes are not yet known, nor is it known how large a fraction may constitute the "leukemic stem cells" or what their proliferative behavior may be. c) The thymidine- ${ }^{3} \mathrm{H}-$ labeled cohort is presumably representative of proliferating blasts when the disease is in full relapse, but one cannot assume that the relatively few blasts which survive during remission have the same $T_{G}$. No information is available about the latter. Further, chemotherapy may result in prolongation of the $T_{G}$, either as a result of selective killing of more rapidly dividing cells or of slowing the growth of surviving blasts that are (sublethally) damaged (55). Such an effect has pre- viously been demonstrated in L1210 mouse leukemia (70) and in the free ascitic cancer cells in a patient with ovarian carcinoma (15).

\section{Mean blood transit time}

The upper limit for the mean transit time of the circulating blasts was about 36 hours in our patients and about 33 hours in two patients studied by Killmann and his associates (9). The fate of these blasts could not be determined from our studies. However, in autotransfusion experiments with circulating acute leukemic blasts labeled in vitro with uridine $-{ }^{3} \mathrm{H}$, we have found their rate of disappearance to be similar to that of the highly labeled blasts in the present studies (55). Most of the uridine $-{ }^{3} \mathrm{H}$-labeled cells disappeared without returning to the marrow and resuming proliferation. As normal myeloblasts are of course confined to the marrow, no comparable figures are available. The mean blood transit time of normal neutrophiles has been established as 9.4 (range 5.1 to 13 ) hours by means of labeling with diisopropylfuorophosphate- ${ }^{32} \mathrm{P}(71)$.

\section{Total number of dividing blasts}

Killmann and co-workers (9) estimated that the total number of dividing blasts in one patient with acute leukemia was $2.5 \times 10^{11}$; the patient's weight was not given, but if it is assumed to have been $70 \mathrm{~kg}$, this would be about $3.5 \times 10^{9}$ blasts per $\mathrm{kg}$. In our patients the values were 1.6 and $2.6 \times 10^{9}$ per $\mathrm{kg}$.

Frei and Freireich (67) have estimated that the total number of leukemic cells present in the bone marrow, spleen, and liver of four children, 10 to 14 years old, who died with acute lymphocytic leukemia was $1.65 \times 10^{12}\left(1.3\right.$ to $\left.1.8 \times 10^{12}\right)$. If one assumes an average weight of $40 \mathrm{~kg}$, this would be about $4 \times 10^{10}$ cells per $\mathrm{kg}$ or more than ten times the number arrived at in the present study. The most plausible explanation for this discrepancy lies in the inherent differences in the methods used. Frei and Freireich (67) used Chalkley counts (72) to determine the total number of leukemic cells, whereas the method we used measures the minimal number of blasts that must be actively dividing to maintain a constant number in the circulation. Blasts marginated on vessel 
walls, those in tissue infiltrates without free access to the blood, and those dying or in a nondividing state are not included.

Our methods are not applicable to normal hematopoietic precursors. Previous estimates have varied considerably $(73,74)$; Killmann, Cronkite, Fliedner, and Bond (1) considered the best estimates to be $3.5 \times 10^{9}$ per $\mathrm{kg}$ for erythroid precursors and $8.8 \times 10^{9}$ per $\mathrm{kg}$ for neutrophiles and their precursors in the marrow.

\section{Effects of thymidine ${ }^{3} \mathrm{H}$ on proliferation parame- ters}

With the doses used in our two patients $(0.26$ and $0.34 \mu \mathrm{c}$ per $\mathrm{g}$, SA $6.6 \mathrm{c}$ per mmole), it is unlikely that the time parameters of proliferation were appreciably altered either by intranuclear tritium or by exogenous thymidine. In animal experiments in which thymidine- ${ }^{3} \mathrm{H}$ has been administered in vivo, doses of $1 \mu \mathrm{c}$ per $\mathrm{g}$ or greater $(18,75-78)$ have been necessary to produce acute toxic effects such as lengthening of the generation time or of DNA synthesis time (77), disruption of the rhythm of the replication cycle (77), mitotic abnormalities $(75,77)$, reduction in the mitotic rate $(75,77)$, or cell death $(18,78)$. In our studies there was no discernible effect on the mitotic index or on the incidence of mitotic abnormalities, even among the most highly labeled cells.

One can compute $(18,76)$ that blasts with 100 grains in our studies received an average maximal dose to the nucleus of about 360 rads during the first day (provided they did not divide until 24 hours after incorporating the thymidine ${ }^{3} \mathrm{H}$ ). With 100 grains per nucleus (estimated minimal volume $200 \mu^{3}$ ), after a 14-day exposure period, if one assumes a radioautographic efficiency of $1 \%$, there are 714 disintegrations per day. Since 60 disintegrations produce an average of 30 rads to a $200-\mu^{3}$ nucleus $(18,76)$, the average daily dose to these nuclei is approximately $(714 / 60)$ $\times 30$ rads $=357$ rads. It might be expected that such highly labeled cells would suffer some radiation damage. Although we could find no evidence from the grain count data that there was any slowing in DNA synthesis or delay in entry into their first division, it is possible that subsequent divisions were inhibited. In a previous study in a patient with a neoplastic effusion whose cancer cells incorporated over ten times as much thymidine $-{ }^{3} \mathrm{H}$ as the leukemic blasts, the most highly labeled cells showed retardation in DNA synthesis and delayed entry into their first mitosis, and they failed to undergo subsequent divisions (15).

Whereas large amounts (about 2 to 5 mmoles per L) of thymidine have been shown to inhibit cellular multiplication in vitro (40-44), smaller amounts (about $1.5 \times 10^{-6}$ mmoles per $\mathrm{g}$ body weight) have been shown to stimulate mitotic activity in the duodenal epithelium of mice in vivo (79). It was postulated that this stimulatory effect was due to shortening of DNA synthesis time as a consequence of a significant expansion of the body thymidine pool (79-81). No significant increase in mitotic index was observed in the blasts of either of our patients after thymidine- ${ }^{3} \mathrm{H}$ administration. As the total amounts given were only 4.3 and $5.2 \times 10^{-8}$ mmole per $\mathrm{g}$ of body weight, it seems unlikely that doses of this magnitude would influence cellular replication.

\section{Normal hematopoietic cells in acute leukemia}

It is of considerable importance to define as precisely as possible the disorder responsible for depletion of normal hematopoietic cells in acute leukemia. If this were possible, it would not only clarify the interrelationships between leukemic and normal cells but might also lead to a better understanding of normal regulatory mechanisms as well as the nature of the essential defect in leukemic cells.

At the time thymidine- ${ }^{3} \mathrm{H}$ was administered, both our patients were severely anemic and had reduced numbers of erythroid precursors in the marrow. The absolute number of granulocytes was severely reduced in M.T., but only slightly so in R.R.

Erythropoiesis. In Table II are listed estimates of the parameters of proliferation and maturation of the erythrocytic precursors that it was possible to measure in our two patients and the comparable findings in the one hematopoietically normal subject who has been studied by similar methods $(6$, $17,18,32)$. By computing the flow rate of cells through the maturation compartments, Cronkite and associates concluded that there is no ineffective erythropoiesis in the normal individual (in 
TABLE II

Estimated parameters of erythropoiesis

\begin{tabular}{|c|c|c|c|c|c|c|c|c|c|}
\hline & \multicolumn{3}{|c|}{ Basophilic normoblasts } & \multicolumn{3}{|c|}{ Polychromatic normoblasts } & \multicolumn{3}{|c|}{ Orthochromatic normoblasts } \\
\hline & M.T. & R.R. & Normal* & M.T. & R.R. & Normal* & M.T. & R.R. & Normal* \\
\hline $\begin{array}{l}\text { Initial labeling index, \% } \\
\quad(2 \text { hours })\end{array}$ & 65 & 48 & $80-85(17)$ & 16 & 10 & $50(17)$ & 0 & $\mathbf{0}$ & 0 \\
\hline $\begin{array}{l}\text { Time of maximal } \\
\text { labeling, hours }\end{array}$ & 12 & 21 & $3(17)$ & 12 & 21 & $12(17)$ & 48 & 48 & $24(17)$ \\
\hline $\begin{array}{l}\text { Grain count halving } \\
\text { time, hours }\end{array}$ & 30 & 56 & $29(18)$ & 48 & 55 & $29(18)$ & & & \\
\hline $\begin{array}{l}\text { Time of first appear- } \\
\text { ance labeled cells in } \\
\text { marrow, hours }\end{array}$ & & & & & & & $9-12$ & $13-21$ & $4(17)$ \\
\hline Specific mitotic index, $\%$ & ? & ? & $4.9(46)$ & 4.7 & 1.6 & $5.7(46)$ & & & \\
\hline
\end{tabular}

* References for normal values given in parentheses.

contrast to that found in two patients with pernicious anemia and one with myeloid metaplasia) (32). The basophilic and polychromatic normoblasts in our two leukemic patients had lower initial labeling indexes, were generally slower in reaching maximal labeling, and had slower grain count halving times. The polychromatic normoblasts in R.R. also had a lower mitotic index than the average found by Killmann and his associates (46) in six normal individuals (the range of values was not stated). The exact times of first appearance of labeled orthochromatic normoblasts are not known in the leukemic patients, but in any case they appeared later and reached maximal values more slowly than in the normal subject. An additional difference was that, in general, a higher proportion of more mature nucleated red cells was found in the leukemic patients. In the normal subject $(6)$ the ratios of proerythroblasts $\left(E_{1}\right)$ : large basophilic normoblasts $\left(E_{2}\right)$ :small basophilic normoblasts $\left(E_{3}\right)$ :polychromatic normoblasts $\left(E_{4}\right)$ :orthochromatic normoblasts $\left(E_{5}\right)$ were $1: 2.2: 6.1: 8.1: 19.1$, whereas these ratios were for R.R. : $1: 4.7: 2.0: 30.6: 17.3$, and for M.T. $1: 6.3: 3.3: 43.5: 71.0$. Taken as an isolated finding, the increased proportion of more mature forms (at least in M.T.) could mean either an increased rate of production or else that the cells were passing through these maturation compartments at a slower rate. When considered in conjunction with the previous findings, the latter interpretation is most likely correct. Using the methods formulated by Cronkite and his associates
$(6,17,32)$, we have computed the production rates of the erythroid precursors in each of the five maturation categories (not shown), but our data are not precise enough to establish whether erythropoiesis was wholly effective.

We have measured the same parameters of erythropoiesis in three other patients with untreated acute leukemia, and the results were generally comparable. Thus it appears that the (few) surviving erythropoietic precursors in acute leukemia usually proliferate and mature in a manner similar to that in normal subjects, but at a somewhat slower rate. These conclusions must be regarded as only tentative, since it is not known what the range of normal values may be. Although our data are rather fragmentary, it will be difficult to obtain more complete information when the disease is in relapse because of the paucity of red cell precursors and reluctance to perform even more frequent marrow aspirations. Patients in remission usually have more erythroid precursors and more precise measurements are feasible, but the kinetics of erythropoiesis may be different.

Granulopoiesis. In the same hematologically normal subject used for the studies of erythropoiesis, labeled metamyelocytes first appeared in the marrow at 3 hours and attained maximal labeling about the third day $(31,32)$. By determining the rate of entry of cells into this first nonproliferating compartment, Cronkite and associates concluded that there is probably no ineffective granulopoiesis in normal man. In the marrow, labeled juveniles and bands first ap- 
peared at 12 to 36 hours and reached a peak of labeling around the fourth day. Labeled polymorphonuclear neutrophiles first appeared in the marrow around 2 days and reached a peak by the seventh day $(31,32)$. The time of emergence of bands and polymorphonuclear neutrophiles into the blood was studied in this patient and four others judged to be in a normal steady hematologic state; polymorphonuclear neutrophiles first appeared between 96 and 144 hours and bands about 1 day earlier $(3,17,32)$. The maximal percentage of polymorphonuclear neutrophiles labeled was reached at about 6 to 7 days $(2,3,17)$. In two patients with infections, the emergence times of polymorphonuclear neutrophiles were shorter (48 to 72 hours) (3).

The only normal granulocytic cells suitable for study in our two patients were the metamyelocytes, bands, and polymorphonuclear neutrophiles in R.R. Some of the myelocytes may have been leukemic, and of course there was no sure way to distinguish normal promyelocytes and myeloblasts from leukemic ones. The times at which labeled bands and polymorphonuclear cells first appeared (Figure 9) were similar to those found in normal subjects. The observation that R.R.'s labeled neutrophiles reached a maximum in the blood a day or two sooner may have been influenced by the fact that she had a slight infection. The time of appearance of labeled metamyelocytes in the marrow was slightly slower than in the one normal subject, but this difference may not be significant, since there may have been slight differences in morphological classification. We have studied the same parameters of granulopoiesis in four other patients with acute leukemia and obtained very similar results (55). This is also in agreement with the reported findings in three other leukemic patients $(3,48)$. No definitive conclusions can be made regarding effectiveness of granulopoiesis without precise information on generation and maturation times, but from the evidence presently available it appears that the rate of maturation of residual normal granulocytes is not greatly abnormal in acute leukemia.

\section{Interrelation of leukemic and normal hematopoi- etic cells}

Although the actively dividing leukemic blasts proliferate no faster and most divide more slowly than the normal hematopoietic precursors, the blasts eventually displace the latter. This is mainly because the blasts have largely lost their ability to differentiate; many die either in situ in the marrow or else after being discharged into the circulation, but many others persist in the marrow and continue dividing. The relatively few surviving normal hematopoietic precursors also continue to proliferate, but most of their progeny follow their normal course of differentiation; when they reach a stage of maturity at which they are no longer able to divide, they pass out into the blood as in the normal state and hence do not accumulate in the marrow.

When acute leukemia is in relapse, anemia and thrombocytopenia almost always develop to some degree; granulocytopenia is common, although granulocytosis may also occur, especially during infection. Most previous work has centered on the pathogenesis of anemia in acute leukemia, and it is clear that there may be a number of mechanisms operative in causing anemia, aside from simple displacement of erythroid elements by leukemic cells (82-84). Regardless of the cause, one might expect the hematopoietic system to compensate for any reduction in normal cells either by increasing its rate of production or by increasing the size of its producing plant (e.g., probably by activating more stem cells or other very primitive precursors). The rate at which the intermediate precursors undergo division and maturation is no faster than normal and possibly may be slower (at least in the case of erythroid precursors) ; these events may normally proceed at near maximal rates that cannot be greatly exceeded. Since the total production of normal cells is usually markedly deficient and the rate of intermediate cell production is probably not sufficiently abnormal to account for the deficit, the major defect appears to be in the reduced size of the primary generating compartment. Thus the leukemic cells must somehow prevent the normal stem cells from responding adequately.

Little is known about control of leukopoiesis, but there is evidence that erythropoietin is important in regulating erythropoiesis. Its principal action is to increase the rate at which stem cells differentiate to form proerythroblasts (85-89), although it may also have other actions such 
as stimulating reticulocyte release (89). Serum erythropoietin levels are generally high in acute leukemia (90-92), and the lower the hemoglobin value, the higher the titer (92). The high serum level is a result of both increased production by the kidney and lowered consumption by the reduced mass of erythrocyte precursors (92). There thus appears to be an adequate stimulus to increase production of proerythroblasts, but the response is not adequately fulfilled. There are as yet no clues as to how leukemic cells interfere with the stem cell response, but possible mechanisms include $a$ ) competition for known essential nutrilites or for unknown factors that stimulate cellular growth $(82-84,93), b)$ excessive synthesis of substances by the leukemic cells that might result in end-product inhibition of enzymatic activity or repression of enzymatic synthesis in the normal cells $(93-96), c)$ contact inhibition $(97,98)$, or d) production of a growth inhibitor by the leukemic cells (99-102). None of these postulated mechanisms have been proved operative in acute leukemia, and it is difficult to see how any except possibly the last could account for erythropoietic inhibition in all situations [e.g., both in cases where the marrow is densely replaced by blasts before anemia develops and in cases of "preleukemia" (103-105) where the normal elements may be reduced long before extensive infiltration occurs]. In any case, the leukemic cells are almost invariably able to compete successfully with the normal precursors, but the nature of their advantage is obscure.

When chemotherapy is successful in causing remission, it is because the leukemic cells are more sensitive to the injurious action of the drug than the normal cells (106). This greater sensitivity cannot be explained solely on the basis of differences in rates of proliferation and must be due to other factors (107-109). The leukemic cells are either destroyed or their natural advantage is sufficiently diminished and the surviving normal cells are then able to repopulate the marrow. The proliferation kinetics of human leukemia are considerably more complicated than those in transplanted mouse leukemia, in which all, or nearly all, the leukemic cells proliferate exponentially (110-114). Conclusions drawn from mouse experiments may be misleading if applied directly to the human disease. Our present understanding of the growth kinetics of human leukemia is too incomplete to be able to rationally formulate the most effective treatment during different stages of the disease. Until more information is available, the selection of treatment schedules with active drugs must remain largely empirical.

\section{Acknowledgments}

We are especially grateful to the following among our colleagues for helpful advice and criticism: Drs. Victor Bond, David Karnofsky, Fredrik Lottsfeldt, Seymour Perry, Sol Rubinow, and William Siler; and for technical assistance to Mrs. Annabel Strife, Miss Alice Simmons, and Miss Ann Garland.

\section{References}

1. Killmann, S. A., E. P. Cronkite, T. M. Fliedner, and V. P. Bond. Mitotic indices of human bone marrow cells. III. Duration of some phases of erythrocytic and granulocytic proliferation computed from mitotic indices. Blood 1964, 24, 267.

2. Fliedner, T. M., E. P. Cronkite, and J. S. Robertson. Granulocytopoiesis. I. Senescence and random loss of neutrophilic granulocytes in human beings. Blood 1964, 24, 402.

3. Fliedner, T. M., E. P. Cronkite, S. A. Killmann, and V. P. Bond. Granulocytopoiesis. II. Emergence and pattern of labeling of neutrophilic granulocytes in humans. Blood 1964, 24, 683.

4. Cronkite, E. P., and T. M. Fliedner. Granulocytopoiesis. New Engl. J. Med. 1964, 270, 1347, 1403.

5. Lajtha, L. G. Recent studies in erythroid differentiation and proliferation. Medicine (Baltimore) 1964, 43, 625.

6. Cronkite, E. P. Erythropoietic cell proliferation in man. Medicine (Baltimore) 1964, 43, 635.

7. Stryckmans, P., E. P. Cronkite, J. Fache, T. M. Fliedner, and J. Ramos. DNA synthesis time of erythropoietic and granulopoietic cells in human beings. Nature (Lond.) 1966, 211, 717.

8. Cronkite, E. P. Kinetics of proliferation of normal and leukemic leukocytes. The Wistar Institute Symposium Monograph no. 4 in Methodological Approaches to the Study of Leukemias, V. Defendi, Ed. Philadelphia, Wistar Institute Press, 1965, p. 51.

9. Killmann, S. A., E. P. Cronkite, J. S. Robertson, T. M. Fliedner, and V. P. Bond. Estimation of phases of the life cycle of leukemic cells from labeling in human beings in vivo with tritiated thymidine. Lab. Invest. 1963, 12, 671. 
10. Gavosto, F., G. Maraini, and A. Pileri. Nucleic acids and protein metabolism in acute leukemia cells. Blood 1960, 16, 1555.

11. Mauer, A. M. Characteristics of cell proliferation in a patient with acute leukaemia. Lancet 1964, 2, 675.

12. Gavosto, F. Nucleic acids and protein metabolism of bone marrow cells studied by means of tritiumlabeled precursors in Tritium in the Physical and Biological Sciences. Vienna, International Atomic Energy Agency, 1962, vol. 2, p. 237.

13. Killmann, S.-A. Proliferative activity of blast cells in leukemia and myelofibrosis. Morphological differences between proliferating and non-proliferating blast cells. Acta med. scand. 1965, 178, 263.

14. Gavosto, F., A. Pileri, C. Bachi, and L. Pegoràro. Proliferation and maturation defect in acute leukæmia cells. Nature (Lond.) 1964, 203, 92.

15. Clarkson, B., K. Ota, T. Ohkita, and A. O'Connor. Kinetics of proliferation of cancer cells in neoplastic effusions in man. Cancer (Philad.) 1965, 18, 1189.

16. Feller, W. An Introduction to Probability Theory and Its Applications. New York, John Wiley, 1957, vol. 1, p. 146.

17. Bond, V. P., T. M. Fliedner, E. P. Cronkite, J. R. Rubini, and J. S. Robertson. Cell turnover in blood and blood-forming tissues studied with tritiated thymidine in The Kinetics of Cellular Proliferation, F. Stohlman, Jr., Ed. New York, Grune \& Stratton, 1959, p. 188.

18. Cronkite, E. P., T. M. Fliedner, S. A. Killmann, and J. R. Rubini. Tritium-labeled thymidine $\left(\mathrm{H}^{3} \mathrm{TDR}\right)$ : its somatic toxicity and use in the study of growth rates and potentials in normal and malignant tissue of man and animals in Proceedings Series. Tritium in the Physical and Biological Sciences. Vienna, International Atomic Energy Agency, 1962, vol. 2, p. 189.

19. Hughes, W. L., V. P. Bond, G. Brecher, E. P. Cronkite, R. B. Painter, H. Quastler, and F. G. Sherman. Cellular proliferation in the mouse as revealed by autoradiography with tritiated thymidine. Proc. nat. Acad. Sci. (Wash.) 1958, 44, 476.

20. Killmann, S. A., E. P. Cronkite, T. M. Fliedner, and V. P. Bond. Cell proliferation in multiple myeloma studied with tritiated thymidine in vivo. Lab. Invest. 1962, 11, 845.

21. Koburg, E. The use of grain counts in the study of cell proliferation. Cell proliferation in A Guiness Symposium Held at University of Dublin, Trinity College, L. F. Lamerton and R. J. M. Fry, Eds. Philadelphia, F. A. Davis, 1963, p. 62.

22. Quastler, H., and F. G. Sherman. Cell population kinetics in the intestinal epithelium of the mouse. Exp. Cell. Res. 1959, 17, 420.

23. Baserga, R. The relationship of the cell cycle to tumor growth and control of cell division: a review. Cancer Res. 1965, 25, 581.
24. Rubini, J. R., E. P. Cronkite, V. P. Bond, and T. M. Fliedner. The metabolism and fate of tritiated thymidine in man. J. clin. Invest. 1960, 39, 909.

25. Howard, A., and S. R. Pelc. Synthesis of desoxyribonucleic acid in normal and irradiated cells and its relation to chromosome breakage. Heredity 1953, 6 (suppl.), 261.

26. Painter, R. B., and R. M. Drew. Studies on deoxyribonucleic acid metabolism in human cancer cell cultures (HeLa). I. The temporal relationships of deoxyribonucleic acid synthesis to mitosis and turnover time. Lab. Invest. 1959, 8, 278.

27. Cleaver, J. E. The relationship between the duration of the $S$ phase and the fraction of cells which incorporate ${ }^{3} \mathrm{H}$-thymidine during exponential growth. Exp. Cell Res. 1965, 39, 697.

28. Goldstein, A. Biostatistics: An Introductory Text. New York, Macmillan, 1964, p. 136.

29. Gregerson, M. I., and R. A. Rawson. Blood volume. Physiol. Rev. 1959, 39, 307.

30. Diggs, L. W. The Morphology of Human Blood Cells. Philadelphia, Saunders, 1956, p. 1.

31. Cronkite, E. P., V. P. Bond, T. M. Fliedner, and S. Killmann. The use of tritiated thymidine in the study of haemopoietic cell proliferation in Ciba Foundation Symposium on Haemopoiesis, G. E. W. Wolstenholme and M. O'Connor, Eds. Boston, Little, Brown, 1960, p. 70.

32. Cronkite, E. P., T. M. Fliedner, P. Strychmans, A. D. Chanana, J. Cuttner, and J. Ramos. Aplastic anaemia. Flow patterns and rates of human erythropoiesis and granulocytopoiesis. Series Haematologica (Copenhagen) 1965, 5, 51.

33. Bryant, B. J. Reutilization of leukocyte DNA by cells of regenerating liver. Exp. Cell Res. 1962, 27, 70.

34. Bryant, B. J. Reutilization of lymphocyte DNA by cells of intestinal crypts and regenerating liver. J. Cell Biol. 1963, 18, 515.

35. Baserga, R., and W. E. Kisieleski. Comparative study of the kinetics of cellular proliferation of normal and tumorous tissue with the use of tritiated thymidine. I. Dilution of the label and migration of labeled cells. J. nat. Cancer Inst. 1962, 28, 331.

36. Diderholm, H., K. E. Fichtelius, and O. Linder. Availability time of ${ }^{3} \mathrm{H}$-label after administration of ${ }^{3} \mathrm{H}$-thymidine in vivo. Exp. Cell Res. 1962, 27, 431.

37. Rieke, W. O. The in vivo reutilization of lymphocytic and sarcoma DNA by cells growing in the peritoneal cavity. J. Cell Biol. 1962, 13, 205.

38. Robinson, S. H., and G. Brecher. Delayed incorporation of tritiated thymidine into DNA. Science 1963, 142, 392.

39. Feinendegen, L. E., V. P. Bond, E. P. Cronkite, and W. L. Hughes. RNA turnover in normal rat bone marrow. Ann. N. Y. Acad. Sci. 1964, 113, 727. 
40. Xeros, N. Deoxyriboside control and synchronization of mitosis. Nature (Lond.) 1962, 194, 682.

41. Morris, N. R., and G. A. Fischer. Studies concerning inhibition of the synthesis of deoxycytidine by phosphorylated derivatives of thymidine. Biochim. biophys. Acta (Amst.) 1960, 42, 183.

42. Bootsma, D., L. Budke, and O. Vos. Studies on synchronous division of tissue culture cells initiated by excess thymidine. Exp. Cell Res. 1964, 33, 301.

43. Gentry, G. A., P. A. Morse, Jr., D. H. Ives, R. Gebert, and V. R. Potter. Pyrimidine metabolism in tissue culture cells derived from rat hepatomas. II. Thymidine uptake in suspension cultures derived from the Novikoff hepatoma. Cancer Res. 1965, 25, 509.

44. Gentry, G. A., P. A. Morse, Jr., and V. R. Potter. Pyrimidine metabolism in tissue culture cells derived from rat hepatomas. III. Relationship of thymidine to the metabolism of other pyrimidine nucleosides in suspension cultures derived from the Novikoff hepatoma. Cancer Res. 1965, 25, 517.

45. Mauri, C. DNA synthesis and mitotic rate of leukemic cells. Cancro 1962, 15, 145.

46. Killmann, S., E. P. Cronkite, T. M. Fliedner, and V. P. Bond. Mitotic indices of human bone marrow cells. I. Number and cytologic distribution of mitoses. Blood 1962, 19, 743.

47. Lala, P. K., M. A. Maloney, and H. M. Patt. Measurement of DNA-synthesis time in myeloiderythroid precursors. Exp. Cell Res. 1965, 38, 626.

48. Mauer, A. M., and V. Fisher. In vivo study of cell kinetics of acute leukæmia. Nature (Lond.) 1963, 197, 574.

49. Clarkson, B., K. Ota, T. Ohkita, and A. O'Connor. Cellular proliferation in acute leukemia. Proc. Amer. Ass. Cancer Res. 1964, 5, 43.

50. Mauer, A. M., and V. Fisher. Comparison of the proliferative capacity of acute leukæmia cells in bone marrow and blood. Nature (Lond.) 1962, 193, 1085.

51. Clarkson, B., T. Ohkita, K. Ota, and A. O'Connor. Studies of cellular proliferation in acute leukemia (abstract). J. clin. Invest. 1965, 44, 1035.

52. Roll, K., and S. A. Killmann. Pathology. Lack of diurnal variation in tritiated thymidine labelling index of human leukæmic blast cells. Nature (Lond.) 1965, 205, 1235.

53. Astaldi, G., and M. Ravetta. Studio anatomofunzionale del midollo osseo nella leucemia acuta. Haematologica 1942, 24, 657.

54. Lala, P. K., M. A. Maloney, and H. M. Patt. A comparison of two markers of cell proliferation in bone marrow. Acta haemat. (Basel) 1964, 31, 1.

55. Clarkson, B., T. Ohkita, and K. Ota. Unpublished observations.
56. Ota, K. Kinetics of cellular proliferation in leukemia and cancer. Acta haemat. jap. 1964, 27, 693.

57. Edwards, J. L., A. L. Koch, P. Youcis, H. L. Freese, M. B. Laite, and J. T. Donalson. Some characteristics of DNA synthesis and the mitotic cycle in Ehrlich ascites tumor cells. J. biophys. biochem. Cytol. 1960, 7, 273.

58. Stanners, C. P., and J. E. Till. DNA synthesis in individual L-strain mouse cells. Biochim. biophys. Acta (Amst.) 1960, 37, 406.

59. Painter, R. B., R. M. Drew, and B. G. Giauque. Further studies on deoxyribonucleic acid metabolism in mammalian cell cultures. Exp. Cell Res. 1960, 21, 98.

60. Howard, A., and D. L. Dewey. Non-uniformity of labelling rate during DNA synthesis. Exp. Cell Res. 1961, 24, 623.

61. Newton, A. A., and P. Wildy. Parasynchronous division of HeLa cells. Exp. Cell Res. 1959, 16, 624.

62. Wimber, D. E. Asynchronous replication of deoxyribonucleic acid in root tip chromosomes of $\mathrm{Tra}$ descantia paludosa. Exp. Cell Res. 1961, 23, 402.

63. Terasima, T., and L. J. Tolmach. Growth and nucleic acid synthesis in synchronously dividing populations of HeLa cells. Exp. Cell Res. 1963, $30,344$.

64. Gavosto, F., A. Pileri, L. Pegoraro, and A. Momigliano. In vivo incorporation of tritiated thymidine in acute leukæmia chromosomes. Nature (Lond.) 1963, 200, 807.

65. Boll, I., and A. Kühn. Granulocytopoiesis in human bone marrow cultures studied by means of kinematography. Blood 1965, 26, 449.

66. Mauer, A. M., and V. Fisher. Maturation defect of leukemic blast cells in acute leukemia. J. clin. Invest. 1965, 44, 1074.

67. Frei, Emil III, and E. J. Freireich. Progress and perspectives in the chemotherapy of acute leukemia. Advanc. Chemother. 1965, 2, 269.

68. Ellison, R. R., and M. L. Murphy. "Apparent doubling time" of leukemic cells in marrow (abstract). Clin. Res. 1964, 12, 284.

69. Johnson, H. A., W. E. Haymaker, J. R. Rubini, T. M. Fliedner, V. P. Bond, E. P. Cronkite, and W. L. Hughes. A radioautographic study of a human brain and glioblastoma multiforme after the in vivo uptake of tritiated thymidine. Cancer (Philad.) 1960, 13, 636.

70. Johnson, R. E., M. Zelen, and N. H. Kemp. Chemotherapeutic effects of mammalian tumor cells. I. Modification of leukemia L1210 growth kinetics and karyotype with an alkylating agent. J. nat. Cancer Inst. 1965, 34, 277.

71. Mauer, A. M., J. W. Athens, H. Ashenbrucker, G. E. Cartwright, and M. M. Wintrobe. Leukokinetic studies. II. A method for labeling granulo- 
cytes in vitro with radioactive diisopropyfluorophosphate $\left(\mathrm{DFP}^{32}\right)$. J. clin. Invest. 1960, 39, 1481.

72. Chalkley, H. W. Method for the quantitative morphologic analysis of tissues. J. nat. Cancer Inst. 1943-44, 4, 47.

73. Patt, H. M. A consideration of myeloid-erythroid balance in man. Blood 1957, 12, 777.

74. Osgood, E. E. Number and distribution of human hemic cells. Blood 1954, 9, 1141.

75. Grisham, J. W. Inhibitory effect of tritiated thymidine on regeneration of the liver in the young rat. Proc. Soc. exp. Biol. (N. Y.) 1960, 105, 555.

76. Hughes, W. L. Discussion of radiation effects of cellular labels in The Kinetics of Cellular Proliferation, F. Stohlman, Jr., Ed. New York, Grune \& Stratton, 1959, p. 135.

77. Post, J., and J. Hoffman. Dose-determined effects of $\mathrm{H}_{3} \mathrm{TDR}$ as DNA label upon the liver cell replication time and pattern in the growing rat. Pure appl. Chem. 1964, 8, 499.

78. Garder, K. H., and F. Devik. Studies on the incorporation of tritiated thymidine in deoxyribonucleic acid in mouse tissues and on its radiation effects. Int. J. Radiat. Biol. 1963, 6, 157.

79. Greulich, R. C., I. L. Cameron, and J. D. Thrasher. Stimulation of mitosis in adult mice by administration of thymidine. Proc. nat. Acad. Sci. (Wash.) 1961, 47, 743.

80. Lajtha, L. G. The effect of radiations on nucleic acid metabolism in The Nucleic Acids, E. Chargaff and J. N. Davidson, Eds. New York, Academic Press, 1960, vol. 3, p. 527.

81. Lajtha, L. G., and R. Oliver. The application of autoradiography in the study of nucleic acid metabolism. Lab. Invest. 1959, 8, 214.

82. Reisner, E. H., Jr. The nature and significance of megaloblastic blood formation. Blood 1958, 13, 313.

83. Dameshek, W., and F. Gunz. Special features in Leukemia, 2nd ed. New York, Grune \& Stratton, 1964, p. 319.

84. Troup, S. B., S. N. Swisher, and L. E. Young. The anemia of leukemia. Amer. J. Med. 1960, 28, 751.

85. Alpen, E. L., and D. Cranmore. Observations on regulation of erythropoiesis and on cellular dynamics by $\mathrm{Fe}^{59}$ autoradiography in The Kinetics of Cellular Proliferation, F. Stohlman, Jr., Ed. New York, Grune \& Stratton, 1959, p. 290.

86. Erslev, A. J. The effect of anemic anoxia on the cellular development of nucleated red cells. Blood 1959, 14, 386.

87. Erslev, A. J. Erythropoietin in vitro in Erythropoiesis, L. O. Jacobson and M. Doyle, Eds. New York, Grune \& Stratton, 1962, p. 275.

88. Stohlman, F., Jr., G. Brecher, and R. R. Moores. Humoral regulation of erythropoiesis. VIII. The kinetics of red cell production and the effect of erythropoietin in Erythropoiesis, L. O. Jacobson and M. Doyle, Eds. New York, Grune \& Stratton, 1962, p. 162.

89. Lange, R. D., and V. Pavlovic-Kentera. Erythropoietin. Progr. Hemat. 1964, 4, 72.

90. Van Dyke, D. C., M. Layrisse, J. H. Lawrence, J. F. Garcia, and M. Pollycove. Relation between severity of anemia and erythropoietin titer in human beings. Blood 1961, 18, 187.

91. Penington, D. G. The role of the erythropoietic hormone in anæmia. Lancet 1961, 1, 301.

92. Thorling, E. B. Erythropoietin in serum from patients with leucosis assays in starved rats. Scand. J. Haemat. 1965, 2, 36.

93. Eagle, H. Metabolic controls in cultured mammalian cells. Science 1965, 148, 42.

94. Davis, B. D. The teleonomic significance of biosynthetic control mechanisms. Cold Spr. Harb. Symp. quant. Biol. 1961, 26, 1.

95. Umbarger, H. E. End-product inhibition of the initial enzyme in a biosynthetic sequence as a mechanism of feedback control in Control Mechanisms in Cellular Processes, D. M. Bonner, Ed. New York, Ronald, 1961, p. 67.

96. Yates, R. A., and A. B. Pardee. Control of pyrimidine biosynthesis in Escherichia coli by a feedback mechanism. J. biol. Chem. 1956, 221, 757.

97. Abercrombie, M., and E. J. Ambrose. The surface properties of cancer cells. A review. Cancer Res. 1962, 22, 525.

98. Levine, E. M., Y. Becker, C. W. Boone, and H. Eagle. Contact inhibition, macromolecular synthesis, and polyribosomes in cultured human diploid fibroblasts. Proc. nat. Acad. Sci. (Wash.) 1965, 53, 350.

99. Cohen, E. P., and H. Eagle. A simplified chemostat for the growth of mammalian cells : characteristics of cell growth in continuous culture. J. exp. Med. 1961, 113, 467.

100. Abercrombie, M., J. E. M. Heaysman, and H. M. Karthauser. Social behaviour of cells in tissue culture. III. Mutual influence of sarcoma cells and fibroblasts. Exp. Cell Res. 1957, 13, 276.

101. Oldfield, F. E. Orientation behavior of chick leucocytes in tissue culture and their interactions with fibroblasts. Exp. Cell Res. 1963, 30, 125.

102. Shelton, J. Effect of tumor cells on pre-existing collagen and on collagen production by normal cells grown in diffusion chambers. J. nat. Cancer Inst. 1964, 32, 709.

103. Block, M., L. O. Jacobson, and W. F. Bethard. Preleukemic acute human leukemia. J. Amer. med. Ass. 1953, 152, 1018.

104. Meacham, G. C., and A. S. Weisberger. Early atypical manifestations of leukemia. Ann. intern. Med. 1954, 41, 780.

105. Williams, M. J. Myeloblastic leukemia preceded by prolonged hematologic disorder. Blood 1955, 10, 502. 
106. Karnofsky, D. A., and B. D. Clarkson. Cellular effects of anticancer drugs. Ann. Rev. Pharmacol. 1963, 3, 357.

107. Brockman, R. W. Biochemical aspects of mercaptopurine inhibition and resistance. Cancer Res. 1963, 23, 1191.

108. Werkheiser, W. C. The biochemical, cellular, and pharmacological action and effects of the folic acid antagonists. Cancer Res. 1963, 23, 1277.

109. Bertino, J. R. The mechanism of action of folate antagonists in man. Cancer Res. 1963, 23, 1286.

110. Skipper, H. E. Perspectives in cancer chemotherapy: therapeutic design. Cancer Res. 1964, 24, 1295.

111. Friedkin, M., and A. Goldin. The use of dihydrofolate reductase in studies of mixed populations of sensitive and resistant leukemic cells. Cancer Res. 1962, 22, 607.

112. Skipper, H. E., F. M. Schabel, Jr., and W. S. Wilcox. Experimental evaluation of potential anticancer agents. XIII. On the criteria and kinetics associated with 'curability' of experimental leukemia. Cancer Chemother. Rep. 1964, 35, 1.

113. Goldin, A., J. M. Venditti, S. R. Humphreys, and $\mathrm{N}$. Mantel. Influence of the concentration of leukemic inoculum on the effectiveness of treatment. Science 1956, 123, 840.

114. Venditti, J. M., and A. Goldin. Chemotherapy of advanced mouse leukemia L1210: comparison of methotrexate alone and in sequential therapy. Cancer Res. 1964, 24, 1457.

\section{ANNOUNCEMENT OF MEETINGS}

The American Federation for Clinical Research will hold its Twentyfourth Annual Meeting in Atlantic City, N. J., in the Pennsylvania Room, Haddon Hall, on Sunday, April 30, 1967, at 9:00 a.m. Joint sectional meetings with The American Society for Clinical Investigation will be held on Sunday afternoon at Chalfonte-Haddon Hall, and additional meetings sponsored by The American Federation for Clinical Research will be held on Sunday evening.

The American Society for Clinical Investigation, Inc., will hold its Fifty-ninth Annual Meeting in Atlantic City, N. J., on Monday, May 1, at 9:00 a.m., in the Pennsylvania Room, Haddon Hall, and will join The American Federation for Clinical Research in simultaneous sectional meetings on Sunday afternoon, April 30, at Chalfonte-Haddon Hall.

The Association of American Physicians will hold its Eightieth Annual Meeting in Atlantic City, N. J., in the Pennsylvania Room, Haddon Hall, on Tuesday, May 2, at 9:30 a.m., and in the Vernon Room on Wednesday, May 3, at 9:30 a.m. 